\title{
Service fitness ladders: improving business performance in low cost or differentiated markets
}

Article

Accepted Version

Hill, A., Cuthbertson, R., Brown, S. and Laker, B. (2017) Service fitness ladders: improving business performance in low cost or differentiated markets. International Journal of Operations \& Production Management, 37 (10). pp. 12661303. ISSN 0144-3577 doi: https://doi.org/10.1108/IJOPM-032016-0142 Available at https://centaur.reading.ac.uk/82473/

It is advisable to refer to the publisher's version if you intend to cite from the work. See Guidance on citing.

To link to this article DOI: http://dx.doi.org/10.1108/IJOPM-03-2016-0142

Publisher: Emerald

All outputs in CentAUR are protected by Intellectual Property Rights law, including copyright law. Copyright and IPR is retained by the creators or other copyright holders. Terms and conditions for use of this material are defined in the End User Agreement.

www.reading.ac.uk/centaur 
Central Archive at the University of Reading

Reading's research outputs online 


\title{
Service fitness ladders:
}

\section{Improving business performance in low cost or differentiated markets}

\begin{abstract}
Purpose

This paper presents thirteen propositions about how internal strategic fit (often referred to as fit) impacts the business performance of low cost and differentiated services. It then uses these relationships to develop two 'fitness ladder' frameworks to help practitioners understand how to improve fit given their business strategy (low cost or differentiation) and performance objectives (operational, financial or competitiveness).
\end{abstract}

\section{Design/methodology/approach}

Eleven strategic business units were studied that perform differently and provide a range of low cost and differentiated services to understand how changes in internal strategic fit impacted business performance over a seven year period.

\section{Findings}

Our findings suggest aligning systems with market needs does not improve performance. Instead, firms serving low cost markets should first focus managers' attention on processes and centralise resources around key processes, before reducing process flexibility and automate as many steps as possible to develop a low cost capability that is difficult to imitate. By contrast, firms serving differentiated markets should first focus managers' attention on customers and then locate resources 
near them, before increasing customer contact with their processes and making them more flexible so they can develop customer knowledge, relationships and services that are difficult to imitate.

\section{Research limitations/implications}

Some significant factors may not have been considered as the study only looked at the impact of fourteen internal strategic fit variables on seven performance variables. Also, the performance changes may not be a direct result of the strategic fit improvements identified and may not generalise to other service organisations, settings and environments.

\section{Practical implications}

The strategic fit-performance relationships identified and the 'fitness ladder' frameworks developed can be used by organisations to make decisions about how best to improve fit given their different market needs, business strategies and performance objectives.

\section{Originality/value}

Our findings offer more clarity than previous research about how internal fit impacts business performance for low cost and differentiated services.

Keywords

Strategic fit; Business performance; Operations strategy; Service operations; Case/field study

Paper type

Research paper 


\section{Introduction}

Strategic fit (often referred to as fit) concerns aligning an organisation's overall objectives and strategy (external fit) and how it makes or delivers this offering (internal fit) with the needs of the market(s) it serves (Miller, 1981; Robinson and Stern, 1998; Boyer and McDermott, 1999; Stepanovich and Mueller, 2002).

Previous research to understand the impact of internal fit on business performance has only looked at a limited number of variables, at a single point in time and across a wide range of organisations serving markets with different needs (such as Safizadeh et al., 1996; Youndt et al., 1996; Kathuria and Davis, 2001; Anand and Ward, 2004; Ketokivi and Schroeder, 2004). As such, past research offers limited use to practitioners supporting markets with different needs and may have missed some significant relationships if performance did not immediately change (Menda and Dilts, 1997; Meredith, 1998; Boyer et al., 2005; Sousa and Voss, 2008). It also only looked at the impact of variables such as inventory and capital investment in manufacturing firms (da Silveira, 2005; da Silveira and Sousa, 2010), which makes their findings less relevant to service organisations whose intangible offerings are provided and consumed at the same time with customers present, or participating, in their delivery (Hill and Hill, 2012).

This paper tries to address these gaps by answering two questions: (1) What is the relationship between internal fit and business performance within service organisations? and (2) What internal fit dimensions are more important for improving performance in low cost or differentiated markets? To answer these questions, we analysed internal fit and performance trends over seven years in eleven strategic business units (SBUs) from the banking, communications, construction, emergency response, engineering, retail and utility industries. 
The following section summarises the current research assessing the impact of strategic fit on performance, showing the key findings from each study and the gap that exists. Sections 3 and 4 then explain the internal fit and performance measures adopted within our research. Section 5 shows how the eleven SBUs were selected, how the internal fit and business performance levels were measured and the significant fit-performance relationships identified. Section 6 then describes the seven year internal fit and performance journeys made by each SBU. Section 7 compares the findings across all eleven SBUs, identifying the significant statistical relationships based on their current internal fit and performance levels, and develops thirteen propositions about how different fit variables impact performance in low cost or differentiated markets. Section 8 then uses these propositions to develop two new 'fitness ladder' frameworks to help practitioners improve business performance in low cost and differentiated markets. Finally, Section 9 discusses the limitations of our research and identifies future research opportunities.

\section{Assessing the impact of strategic fit on business performance}

Table 1 shows the market, business strategy, operations strategy and business performance variables investigated in previous research, while Table 2 summarises the key findings from each study.

\section{Insert Tables 1 and 2 around here}

These analyses highlight four main points. First, no previous research has studied the impact of internal fit on business performance in service organisations. Instead, most of the research conducted to date has looked at organisations making products and is of limited use to organisations delivering services who manage their operations very differently. Some of the variables they have investigated have been included within this study (such as management structure, process flexibility 
and level of automation), but others are too broad to be tested (such as management practices and process choice) and some are not relevant in most services (such as inventory and capital investment). The only service research conducted to date has looked at the impact of external strategic fit on performance. It found that external fit positively impacts financial performance (Smith and Reece, 1999; Rhee and Mehra, 2006) and the level of fit was more important than the type of competitive strategy (defender, prospector, analyser or reactor) chosen by the firm (Smith and Reece, 1999).

Second, each study only looked at only two or three measures of fit on two to six measures of performance and consequently offers limited insight for practitioners facing a broad range of investment opportunities and performance objectives. Instead, our research investigates the impact of fourteen fit variables on eight performance variables to start building a more comprehensive understanding of how fit impacts performance.

Third, previous research has found both positive and negative fit-performance relationships. For example, da Silveira and Sousa (2010) found that fit between 'management structure' and 'process' was negatively related to 'flexibility', whilst Kathuria and Davis (2001) found that fit between 'management practices' and 'performance objectives' was directly related to 'quality', but not 'delivery reliability', 'efficiency', 'quantity' and 'productivity'. This might be because organisations have to perform differently in low cost and differentiated markets. For example, cost is often more important in low cost markets and flexibility more important in differentiated ones. This research, therefore, looks at the impact of fit on performance in companies competing in a range of low cost and differentiated markets. As a result, it starts to help practitioners develop a better understanding of where to invest given their market needs and performance objectives. 
Fourth, studies to date have looked at the relationship between fit and performance at a single point in time rather than how this relationship develops over time. As a result, some significant relationships might have been missed if the change in fit did not immediately impact performance. This research, therefore, looks at fit and performance changes over a seven year period within the eleven SBUs to better understand the relationships that exist.

\section{Measuring internal fit}

The existing academic literature presents a number of service operations strategy frameworks to help organisations align their structures, systems, processes and competitive advantage with market needs, as shown in Table 3.

\section{Insert Table 3 around here}

They suggest market needs should determine where a firm locates its resources (organisational centralisation); how it focuses management attention (management structures); how it measures performance, rewards and develops its employees; how it manages quality and capacity; and the flexibility, automation and level/type of customer contact in the processes used to deliver its services. They also suggest services should be differentiated and competitive barriers to entry developed in a way that matches market needs.

However, none of these frameworks explain how aligning these different variables with market needs impacts performance or in which markets they are more important. Our research, therefore, investigates the impact of all fourteen variables on business performance in firms serving low cost 
or differentiated markets to understand how they impact performance and the optimal sequence for aligning them in markets with different needs.

\section{Measuring business performance}

Several authors (such as Kaplan and Norton, 1992; Chenhall and Langfield-Smith, 2007) suggest assessing business performance using a combination of internal, financial and competitiveness measures. Therefore, our study looks at how internal fit impacts four operational (cost, quality, speed and flexibility); two financial (sales revenue and operating profit); and two competitiveness (domestic market share and customer loyalty) variables relative to competitors. This enabled us to understand how each internal fit variable impacts the competitiveness, operational and financial performance of firm's serving low cost or differentiated markets (Ramanujam and Venkatraman, 1987; Kotha and Swamidass, 2000; Papke-Shields and Malhotra, 2001). Also, measuring performance relative to competitors enabled us to compare the performance of firms operating in markets with different levels of competition, demand patterns, and growth, as these factors will affect all the firms competing in that market.

\section{Case study methodology}

A case study research method was used as it allows questions of 'how, why and what' to be answered and richer insights and explanations to be developed (Eisenhardt, 1989; Meredith, 1998; Voss et al., 2002; Weick, 2007; Wacker, 2008; Ketoviki and Choi, 2014). Appendix 1 explains how cases were selected and investigated; findings compared across them; significant internal fitperformance relationships identified; and propositions about how internal fit impacts business performance developed. 


\subsection{Case study selection}

Using replication logic, the research team worked with a steering group of fourteen executives from the seven participating firms to identify eleven SBUs serving a range of services (see Table 4) to customers with different needs and order volumes (see Figure 1), and with different domestic market share and return on sales relative to their competitors (see Figure 2). Based on the definition used within previous studies (such as Yip et al., 2009; and Denrell et al., 2013), an SBU was classified as 'high performing' if its return on sales and domestic market share was higher than the average of its competitors. This created the rich case database necessary for theory development (Eisenhardt, 1989; Yin, 1994), which enabled the two research questions identified earlier to be answered as it contained cases who had made different internal fit improvements over the last seven years, have performed differently and serve markets with different needs.

\section{Insert Table 4 and Figures 1 and 2 around here}

\subsection{Case study protocol}

The research followed the established case study method for data collection and analysis (Eisenhardt, 1989; Yin, 1994; Voss et al., 2002). After selecting and gaining access to the eleven SBUs, the research team developed the protocol; entered the field; analysed the data; shaped the hypotheses; and enfolded the literature using the steps shown in Appendix 1. Each case study took 5 to 8 months to complete with 6 to 18 company visits, 13 to 36 executive interviews, 31 to 140 direct observations and analysis of 21 to 56 documents and 55 to 109 archival records (see Appendix 2). 
The secondary data sources looked at the seven year fit and performance changes in each company and some of the employees interviewed had also worked there for this length of time.

Interviews were semi-structured, conducted face-to-face and lasted between one and two hours. The executives interviewed reflected the type of organisation and the internal fit or performance aspect being reviewed. For example, more senior executives were interviewed about markets, structures and systems, whereas less senior executives were interviewed about systems and processes. They worked in a range of functions (such as operations, sales, marketing, design, human resource and finance) and levels within the business (from managing director/CEO to three levels beneath them). Interviews started with the managing director/CEO, moved down the hierarchy and stopped when the seven year internal fit and performance journey was clearly and consistently understood by the researchers. Many executives were interviewed multiple times to check points as they emerged from the research.

The insights from these interviews were then tested and extended through further site visits to observe meetings, organisation layouts, where investments had been made, and how services were delivered. Relevant documents were reviewed including performance reports, strategic and investment plans, budget reviews, minutes from meetings, employee rewards, personal development plans and working procedures. Archival records were also reviewed including financial accounts, management reports, industry reports, customer order and communication histories, strategy implementation documents, operational performance reports, organisational charts, office layouts and training records. 
Data were categorised by the research team as data were collected into five areas to understand the following from the SBU's: (1) business performance relative to its competitors;(2) needs of the market(s) it served; (3) structures; (4) systems; and (5) processes it used to deliver services. This iteration between fieldwork and data analysis enabled observations to be empirically grounded and anomalies identified, which advanced the theory-building process (Eisenhardt, 1989; Eisenhardt and Graebner, 2007). Each investigation resulted in a 24 to 33 page report written using the case study protocol showing its seven year internal fit and performance journey.

\subsection{Identifying the internal fit and business performance journey}

Table 5 shows how the seven year internal fit and performance journey in each case study was identified. The variables, definitions and scales used to measure internal fit and business performance on this journey are also shown in Appendices 3 and 4; and the key data used to measure these variables are shown in Appendices 5 and 6. Using these definitions and scales we were able to translate actual (objective not perceptive) internal fit and performance measures as a measure between 0.0 and 5.0 so they could be more easily compared with each other and organisations with high fit or performance more easily identified (with a score of 3.0 or more).

\section{Insert Table 5 around here}

First, we determined how the SBU's operational performance (cost, flexibility, speed and quality), financial performance (operating profit) and competitiveness (domestic market share and customer loyalty) had changed relative to competitors (as a percentage of average competitor performance) over the last seven years by identifying key competitors (industry reports and executive/customer 
interviews), analysing documents (industry reports) and archival records (financial accounts and reports). For example, changes in cost were calculated by observing service delivery, reviewing financial accounts, investment records and management reports, and analysing competitors.

Then, we identified how market needs have changed through interviews (with customers and executives), direct observation (of customer behaviour) and analysis of archival records (market research reports, customer surveys, and historical customer orders) to determine the 'ideal fit' profile over the last seven years. For example, if 'service/product design' was the main orderwinner and 'price' was only a qualifier then the ideal profile would be 0.0 . However, if 'price' was the main order-winner and 'service/product design' was only a qualifier then the ideal profile would be 5.0 (Hill and Hill, 2012).

Changes in the structures, systems and processes used over the last seven years were then identified through interviews (with customers and executives using the questions in Appendix 6); direct observation (of meetings, where investments were made; office layouts; listening to customer telephone calls and/or observing front-office operations); as well as documents and archival records (industry reports, strategic and investment plans, organisation charts, budget reviews, reports, meeting minutes, employee reward and development plans, training records, working procedures and/or office layouts). For example, changes in organisational centralisation were calculated by observing office layouts, and reviewing investment records, office layouts and management structures; whereas changes in process flexibility were determined by observing service delivery, and reviewing procedures and training records. 
To make it easier to compare fit levels and changes between the organisations studied, their actual levels (measured using data gathered through interviews, direct observation, documents and archival records) were converted into a number between 0.0 and 5.0 using the scales shown in Appendix 4. For example, if 20 percent of activities were centralised across operations units, then this was given a weighting of 1.0 (as the scale is 0.0 for 0 percent and 5.0 for 100 percent). Equally, if 80 percent of service quality checks were made using technology/equipment rather than people, then this was given a weighting of 4.0 (as the scale is 0.0 for 0 percent and 5.0 for 100 percent).

However, some of the variables are more difficult to measure precisely so value judgements had to be made by the research team based on all of the data collected (through interviews, direct observation, documents and archival records). For example, the level of low cost capability compared with competitors was measured by comparing the cost structure in each company's annual report, the price of their services and their return on sales. Using this data, the research team decided if the case study had a 'not significant' (giving it a score of 0.0), 'very significant' (a score of 5.0) or somewhere in between (a score weighted between 0.0 and 5.0) low cost capability compared with its competitors.

Finally, our findings were presented back to the executives interviewed to check they agreed with the insights developed and give them opportunity to recall any new information. 


\subsection{Identifying internal fit-performance relationships across all eleven case studies}

The measures, definitions and scales shown in Appendices 3 and 4 were then used to calculate the current level of performance and fit between each structure, system and process variable and its market needs (how orders are won) so the statistical relationships across all eleven case studies could be calculated (Venkatraman, 1989). Spearman's rho was used to calculate these relationships, rather than Pearson's r, because the fit and performance variables might not be normally distributed and the number of cases was relatively small (Mohrman et al., 2001). This approach is consistent with previous studies investigating the relationship between fit and performance such as Naman and Slevin (1993), Choe et al. (1997), Ahmad and Schroeder (2003) and da Silveira (2005).

These relationships were then used to confirm, challenge, understand and explain the internal fit and performance journeys across all eleven SBUs (Wacker, 2008). In some instances, this led to further research to help explain anomalies that emerged.

\section{Within-case descriptions}

Tables 6 and 7 show the seven year internal fit and performance journey within each case study and Table 8 shows their current internal fit and performance levels. The key steps in these journeys are now discussed.

Insert Tables 6, 7 and 8 around here 


\subsection{Low cost markets}

Over the last seven years, Companies 1 and 2 serving low cost markets have both improved internal fit in a number of ways, but their performance is still low. The Domestic Utility Provider (Company 1) set up regional call centres to reduce face-to-face customer contact in its retail outlets and then introduced an automated system for managing quality in these call centres. Although the first step reduced its flexibility, its financial performance and competitiveness did not change. Equally, the Construction Service (Company 2) introduced new cost focused performance measures and linked them to employee rewards and developments, but performance did not significantly change.

However, the other four organisations serving high volume, low cost markets have improved their performance significantly and are now all high performing. The Communications Group (Company 6) first reduced its process flexibility by offering fewer services to its customers and then changed the type of contact with its customers by setting up a self-service website. Both of these changes reduced its flexibility, but only the first one reduced costs and increased profit. These changes created a low cost-base that was difficult for its competitors to imitate and its market share increased. It then introduced cost focused performance measures and linked them to employee reward and development, but performance did not change.

To improve internal fit, the Large-sized Retail Group (Company 7) first set up a matrix management structure, making managers responsible for a key process across the whole organisation as well as all the processes used to design and deliver a particular group of services. As a result, it better understood its processes and started sharing best practice across the organisation. Its costs reduced and profits increased. Customers liked the low cost services it had developed and its market share 
also increased. This capability was difficult for competitors to imitate and, as a result, market share further increased. It then introduced new service development focused performance measures and linked them to employee rewards and developments, but performance did not change.

In contrast to Companies 6 and 7, the Emergency Response Service (Company 8) started by introducing new cost and delivery speed focused performance measures and linked them to employee rewards and developments, but performance did not change. It then moved its back office activities into a central facility to support its fifteen front offices and found costs reduced and profit increased. Within this new facility, it set up functional teams focused on managing and improving processes, which reduced costs and increased profit. Customers liked its low cost services and its market share increased. These functional teams then standardised processes, which reduced flexibility and cost, and increased profit. It then automated 70 percent of its process steps, which further reduced cost and speed, and increased profit.

The Utility Metering Service (Company 9) made similar changes to the Emergency Response Service (Company 8), but in a different order. First, it set up a matrix management structure making managers responsible for all the processes in their operation and a key process across the whole organisation. As a result, costs reduced and both profit and market share increased. Its costs then reduced further as it reduced the flexibility of its processes by offering less services to customers, centralising some back office activities and automating processes in these new 'centres of excellence'. It now had a low cost-base that was difficult for competitors to imitate and, as a result, its market share increased. It then introduced an automated capacity management system, but performance did not change. 


\subsection{Differentiated markets}

Companies 3, 4 and 5 serving differentiated markets are all still low performing even though they have improved their internal fit over the last seven years. The Small-sized Retail Group (Company 3) first increased the number of staff in its stores to increase face-to-face contact, but performance did not change. It then encouraged staff to spend more time with customers to build relationships and understand their needs, which increased quality and profit as customers started buying higher priced services. Processes were then made more flexible so they could deliver more customised services, which increased flexibility and profit. It then introduced 'mystery shoppers', modified employee rewards and developments and introduced new design focused performance measures, but performance did not change.

By contrast, the Large Business Utility Provider (Company 4) first moved its front office activities into a separate facility to serve its large business customers whilst still using a central back office to serve all of its markets (large business, small business and domestic). This increased flexibility, speed and enabled it to understand the true cost of serving its large business customers. As a result, it increased the prices of some services and persuaded some customers to buy more profitable services, which increased profit. It then introduced key account managers in the new 'large business facility' making them responsible for managing customer relationships, understanding their needs and developing new services to meet them. As a result, its quality, profit, market share and customer loyalty increased. Next, it set up a 'customer insight' initiative encouraging staff to spend more time with customers and found both quality and profit increased. It then introduced customer visits to increase face-to-face contact and made staff responsible for managing quality, but performance did not improve. 
The Small Business Utility Provider (Company 5) made similar changes to the Large Business Utility Provider (Company 4), saw similar changes in performance and is also still low performing (see Table 7). However, the other two organisations (Companies 10 and 11) serving low volume, differentiated markets have significantly improved performance over the last seven years and are now both high performing.

The Medium-sized Retail Group (Company 10) first restructured its head office into customer teams making each one responsible for understanding customer needs and developing new services to meet them. As a result, its quality, profit, market share and customer loyalty increased. It then introduced new performance measures focused on customer relationships and new service development and linked them to employee rewards and developments, but performance did not change. Next it moved some activities from its head office to local retail operations so they could customise them to local market needs, which reduced speed and increased flexibility. Profit also increased as it better understood the cost of serving each local market and raised the price of a number of its services. It then increased process flexibility in its retail facilities so they could deliver more customised services, which increased flexibility and profit as it started selling more customised and higher priced services. Staff were then encouraged to spend more time with customers, which further increased quality and profit.

The Product Developer (Company 11) made similar changes to Company 10, but in a different sequence. First, it set up a separate facility to support this market (away from its domestic business) and found speed decreased whilst flexibility and profit increased. Then, it set up customer teams in this new facility and quality, profit, market share and customer loyalty increased. Each team then introduced customer-specific measures, linked them to employee rewards and developments and 
introduced face-to-face customer meetings to manage quality, but performance did not change. It then decided to increase process flexibility so each team could deliver more customised services and found both flexibility and profit increased. It now had customer knowledge and relationships that were difficult for competitors to imitate and its market share and customer loyalty further increased. It then introduced new, more expensive services tailored to specific customer needs, which further increased quality, profit and customer loyalty.

\section{Cross-case comparisons}

Table 9 compares the internal fit and performance journeys made by the six low cost SBUs and Table 10 shows the journeys of the five differentiated SBUs. Table 11 then shows the statistical relationships between internal fit and performance across all eleven SBUs based on the current levels shown earlier in Table 8. The significant relationships highlighted in these tables are now discussed in more detail.

\section{Insert Tables 9, 10 and 11 here}

\subsection{Management structure}

Focusing managers on market needs (through management structures) was the only change that consistently increased both an SBU's profit and market share. This was the case even if an SBU had poor systems and processes as managers worked around them once they were focused on the right things. For example, Companies 7, 8 and 9 serving low cost markets focused managers on processes (through matrix management structures) making them responsible for a process across the 
whole organisation as well as all the processes within their own operation. These new structures enabled them to benchmark performance and share best practice across the business. As a result, overhead and process costs reduced and profit increased. Costs were then sufficiently low for them to reduce prices without significantly reducing profit. This attracted low cost customers from their competitors and market share increased. Interestingly, customer loyalty did not improve though as these customers had little loyalty to any provider and would move to another supplier if offered a cheaper price.

Equally, there were similar performance improvements for Companies 4, 5, 10 and 11 serving differentiated markets when they focused managers on customers (through customer teams) to help build relationships, understand their needs and develop new services to meet them. Quality improved as these new services better met customer needs and profit increased as they were prepared to pay a higher price for them. Market share also increased as the company used their improved design capability and services to attract differentiated customers from competitors. Customer knowledge and relationships also started to increase, which made customers more loyal as they became less willing to move to another supplier who did not know them or understand their needs.

The statistical relationship across all eleven cases based on their current internal fit and performance supports the evidence from the seven case studies who introduced new management structures. Therefore, we forward our first two propositions:

P1: Focusing managers on processes in low cost markets reduces costs and increases market share 
P2: Focusing managers on customers in differentiated markets increases quality, profit, market share and customer loyalty

\subsection{Organisational centralisation}

Locating resources (organisational centralisation) near customers in differentiated markets or centrally in low cost markets helped firms understand the true cost of serving customers, which consistently increased profit. For example, Companies 8 and 9 serving low cost markets found centralising activities increased order volumes and staff utilisation, and reduced order processing times and set ups. This reduced overhead and process costs and increased profit.

By contrast, Companies 4, 5, 10 and 11 serving differentiated markets found moving activities closer to their customers enabled them to build stronger relationships with them and adapt activities to their varying needs. This increased flexibility, reduced the speed of serving customers and meant they also better understood the true cost of serving different customer groups as overheads were no longer spread across the whole business. They found the true cost of serving customers was often higher than previously thought and the improved customer relationships resulting from being located closer to them and improved service levels they were able to provide (through the increased flexibility and reduced speed) enabled them to increase prices or persuade customers to buy more profitable services. As a result, profit increased.

This finding surprised these differentiated companies as they had decentralised activities to improve customer support rather than identify low profit services and customers. However, it did support the 
view of some executives that centralising or decentralising activities every five to seven years helps firms identify the true cost of delivering services and supporting customers.

Again, the evidence from the six organisations was supported by statistical correlations across all eleven companies. As a result, we forward our next two propositions:

P3: Centralising activities in low cost markets decreases overhead costs and increases profit

P4: Moving activities closer to customers in differentiated markets increases flexibility, reduces speed and increases profit as the cost of serving them is better understood

\subsection{Performance measures}

Although aligning performance measures with market needs identified areas of poor market support, it did not improve performance. For example, Companies 2, 6, 7, 8 and 9 serving low cost markets all aligned performance measures with market needs early on as they thought this would improve performance. However, although they better understood the cost of serving their markets and identified areas for improvement, performance did not change. These companies found this surprising as they assumed that 'what gets measured gets done', but performance only changed when they introduced new operating structures or processes later on.

Aligning performance measures with market needs had the same impact in Companies 3, 10 and 11 serving differentiated markets. Although the new measures identified gaps in their service offerings, these gaps were only filled when their operating structures and processes were improved. 
Interestingly, the differentiated companies found this less surprising than the low cost ones as they used performance measures to monitor the impact of structural and process changes rather than expect them to improve performance by themselves. As a result, they introduced them much later on in their development.

The evidence from these eight organisations was supported by the low statistical correlations across all eleven companies. As a result, we forward our next proposition:

P5: Aligning performance measures with market needs identifies poor performance, but does not improve performance

\subsection{Employee rewards and developments}

Aligning employee rewards and developments with market needs motivated staff to make improvements, but performance did not change until new operating structures and processes were introduced. For example, Companies 2, 6, 7, 8 and 9 serving low cost markets all aligned employee rewards and developments with market needs, but performance stayed the same. These companies were surprised by this finding and they had invested significant resources to develop, negotiate and implement new staff contracts expecting this to improve performance.

Similarly, Companies 3, 10 and 11 serving differentiated markets who linked employee rewards and developments to market needs found that while staff were motivated to design and deliver new services, performance did not change. Interestingly, the differentiated companies were less surprised by this finding as they believed employees were already motivated by their work, the customer 
relationships they had built and the positive customer feedback they received when their needs were met. Instead of expecting employee rewards and developments to improve performance, they used them to reward staff for the improvements they had already made.

Again, the statistical correlations across all eleven companies shown in Table 11 support these findings. Therefore, we forward our sixth proposition:

P6: Aligning employee rewards and developments with market needs motivates staff to improve performance, but does not improve performance

\subsection{Flexibility}

Aligning process flexibility with market needs consistently increased profit by reducing costs in low cost markets or enabling firms to deliver more customised and expensive services in differentiated markets. For example, Companies 6, 8 and 9 serving low cost markets all found reducing process flexibility reduced the range of services delivered and increased the order volume for each service. It was therefore easier to make productivity improvements, which impacted a larger number of services and customer orders. As a result, flexibility and process costs reduced and profit increased. Also, their purchasing power increased as services became more standardised, which reduced the cost of buying products or services and further increased profit.

By contrast, Companies 3, 10 and 11 serving differentiated markets also found profit increased when they made processes more flexible as this increased flexibility and enabled them to deliver 
more customised services. Customers were willing to pay more for these new services and profit increased.

Interestingly, none of the low cost or differentiated SBUs found this surprising. However, profit improved more quickly in low cost markets as reducing process flexibility immediately reduced costs. It took longer for profit to increase in differentiated markets as these SBUs had to develop more expensive customised services and change customer behaviour after making their processes more flexible.

Again, the statistical correlation across all eleven companies supports these findings. We therefore forward our next two propositions:

P7: Reducing process flexibility in low cost markets reduces flexibility and increases profit by reducing process costs

P8: Increasing process flexibility in differentiated markets increases flexibility, service customisation and profit

\subsection{Automation}

Companies 8 and 9 serving low cost markets both found automating processes reduced the speed of serving customers and increased profit by reducing direct labour costs. However, both firms said they could not have justified the investment to do this without first increasing order volumes (by centralising activities) and standardising processes (by reducing flexibility). 
Interestingly, none of the companies serving differentiated markets changed their level of process automation in the period studied. When asked why this was, the organisations said they did not have the order volumes to justify such investments and wanted to keep processes flexible so they could customise services to different customer needs.

Again, the correlations across the eleven organisations studied support these findings and therefore we forward our next proposition:

P9: Increasing process automation in low cost markets reduces speed and increases profit by reducing direct labour costs

\subsection{Customer contact}

Increasing customer contact with processes enabled Companies 3, 4, 5, 10 and 11 serving differentiated markets to better understand their the steps that add most value to customers, build better customer relationships, use customers in service design/delivery and increase the level/speed of customer feedback. As a result, they developed services better matched to customer needs and quality further increased. Customers were willing to pay a higher price for these new services and profit increased.

By contrast, there was no evidence of companies serving low cost markets changing the level of customer contact with their processes. When asked why this was, they said they had not thought about it. They assumed they needed to maintain some customer contact, but had not considered proactively trying to reduce it. 
Again, the statistical relationships across all the eleven companies studied support these findings and therefore we forward our next proposition:

P10: Increasing customer contact with processes in differentiated markets increases quality and profit

\subsection{Barriers to entry}

Firms who developed barriers to entry through earlier structural and process developments found this further increased their market share. This was achieved by developing a low cost capability in low cost markets or customer relationships, customer knowledge and a design-capability in differentiated markets that competitors could not imitate.

Companies 6 and 7 serving low cost markets developed barriers to entry through incremental improvements in one process variable (Company 6) or structure variable (Company 7) over a number of years, whereas Companies 8 and 9 achieved it by making improvements across a number of process and structure variables. For example, Company 6 systematically reduced its process flexibility over seven years, whilst Company 7 spent a long time developing its matrix management structure. As a result, although they only they only improved one variable, they were a long way ahead of their competitors in learning how to do this.

By contrast, Companies 8 and 9 both created barriers by focusing managers on key processes, centralising activities and making processes less flexible and more automated. None of their 
competitors have improved such as broad range of variables and it will take them a number of years to catch up.

Rather than creating a low cost capability that is difficult for competitors to imitate, Company 11 serving differentiated markets created barriers to entry through its customer relationships, customer knowledge and design capability. As with Companies 8 and 9, this has resulted from a wide number of structural and process improvements over a number of years (see Table 7). However, this was the only differentiated company to build a barrier to entry.

Further investigation found barriers to entry were more difficult to develop and maintain in differentiated markets because customer relationships are more difficult to maintain as individuals often change roles, sites or organisations. Equally, customer knowledge and design capability often quickly become out of date as customer needs and service technologies continually change. For these reasons, most differentiated firms said it was difficult to keep a customer for more than seven years. However, if barriers can be built, then customers will be more loyal in different markets than low costs ones as there is a perceived risk of moving to a new supplier who might not know them or understand their needs.

By contrast, barriers to entry in low cost markets are less customer-specific and their market needs and service designs are more stable. This means barriers can be built and maintained over a number of years as they are not disrupted by sudden customer, market or service changes.

Again, the statistical correlations across all eleven firms support the evidence discussed above and, therefore, we forward our next two propositions: 
P11: Developing a low cost capability that is difficult for competitors to imitate increases market share in low cost markets

P12: Developing customer relationships, customer knowledge and a design capability that is difficult for competitors to imitate increases market share and customer loyalty in differentiated markets

\subsection{Service differentiation}

As a result of the customer knowledge and design capability developed through earlier structural and process improvements, Company 11 was able to design services that were significantly different to its competitors, which increased quality. The lack of competition meant customers became more loyal and it could charge a higher price for these services, which increased profit.

Interestingly, this was the only firm that managed to achieve this. Further investigation showed it was difficult to maintain service differentiation as competitors could easily copy designs (in differentiated markets) or simply reduce prices (in low cost markets). Company 11 was only able to achieve and maintain its service differentiation by developing significant barriers to entry.

Although there was only evidence of one firm achieving and maintaining service differentiation, the findings were supported by the statistical correlations across all eleven organisations and we therefore forward our next proposition:

P13: Differentiating services in differentiated markets increases quality, profit and customer loyalty 


\section{Practical implications: low cost and differentiation fitness ladder frameworks}

The key relationships identified in the previous section have been used to develop two 'fitness ladder' frameworks to help practitioners better understand how to improve business performance in low cost (Figure 3) or differentiated markets (Figure 4). These frameworks suggest a number of steps to improve fit, the impact that each step will have and the factors that will affect this impact. In many ways, these ladders extend the earlier work of Ferdows looking at how to build fitness in factories (Ferdows and De Meyer, 1990; Ferdows and Thurnheer, 2010). However, he suggests all firms should first improve quality, then speed and finally reduce cost, whereas our findings suggest this sequence depends on their market needs. Firms serving low cost markets should improve cost, flexibility and then speed; but firms serving differentiated markets should improve speed, flexibility and then quality.

Also, our findings suggest the impact of each step will depend on a firm's existing knowledge (process, service or customer), existing capabilities (process or customer relationships) and the nature of the markets it serves (volume or stability). This is now discussed in more detail.

\section{Insert Figures 3 and 4 around here}

\subsection{Low cost markets}

As Figure 3 shows, organisations serving low cost markets should focus managers on processes and centralise resources, before standardising and automating processes. Whilst making these structural and process improvements, they should try to build a low cost capability that is difficult for their competitors to imitate. Each step is now discussed in more detail. 
Step 1: Focus managers on processes. Low cost organisations should first focus managers on processes (by changing their management structures) to better understand how they operate. This will enable them to identify and share best practice across different processes, which will help reduce cost. They can then pass some of this cost reduction on to their customers by reducing prices, which will increase their market share. However, the success of this action depends on how well they understand their processes as they need to eliminate waste without accidentally cutting value adding activities, which would reduce their customer support and market share.

Step 2: Centralise resources. Once managers have been focused on processes, they should then centralise resources around these processes. This would increase order volumes and create opportunities to reduce overhead, material and process costs. However, the size of these opportunities will depend on the volume of services they deliver as this determines how many orders their overheads are spread across, their bargaining power with suppliers and their ability to justify process investments. It is therefore critical to maintain and try to increase customer order volumes wherever possible. For example, it might make sense to accept an unprofitable, high volume customer order if it provides a sufficient opportunity to reduce overhead, material or process costs across the business.

Step 3: Standardise processes. Once these organisations have the right structures in place, they can then start aligning their processes with market needs. First, they should standardise processes to reduce flexibility and cost. However, the success of this will depend on their process knowledge and service volume, which is why it makes sense to first improve their structures (by focusing managers on processes and centralising resources). 
Step 4: Automate processes. As their processes become more standardised and repetitive, they can then be automated to reduce labour cost and the speed of delivering services. This will also release cash as customers are served more quickly and materials are held for shorter periods. It makes sense to automate their most repetitive process steps first, as this will create the largest cost reduction and release the largest amount of cash.

Step 5: Develop low cost barriers to entry. The objective of taking the four previous actions (manage processes, centralise resources, standardise processes and increase automation) was to ultimately develop a low cost capability that is difficult for competitors to imitate. If this can be done, then market share will increase as it is easier to attract and retain customers. However, low cost entry barriers are difficult to sustain as customers are always looking for better deals and competitors often have short-term price promotions. To stay ahead of competitors, they therefore need to continually reduce their costs (by increasing volumes or improving processes) and benchmark them against their competitors (by analysing their prices and annual reports). They should also track developments in other industries (such as new process technologies) that could potentially be adopted by their competitors and eliminate their competitive advantage.

\subsection{Differentiated markets}

By contrast, Figure 4 suggests organisations serving differentiated markets should take a different series of steps to improve their business performance. First, they should focus managers on customers and move resources closer to them, before increasing customer contact with their processes and making them more flexible. Whilst making these structural and process 
improvements, they should try to build customer knowledge, customer relationships and unique services that are difficult for their competitors to imitate. Each step is now discussed in more detail.

Step 1: Focus managers on customers. Differentiated organisations should first focus managers on customers to help build relationships with them and better understand their needs. Using this improved customer knowledge, they can then start to customise services to different needs. This will increase quality and market share as customers prefer these services to the ones offered by their competitors. Customers are also prepared to pay a higher price for these services and profit will increase. They will also become more loyal and stop shopping around as these relationships strengthen and they are more satisfied. However, the speed and size of this performance improvement depends on how quickly managers can develop the customer knowledge and relationships necessary to improve their services.

Step 2: Locate resources near customers. Once the organisation has focused its managers on customers, it should then locate its resources near customers so they can be more easily customised to their needs. This means customers will receive a faster and more flexible service. Also, allocating resources to customers helps the organisation better understand the true cost of serving them and decide which ones to shed or grow. As a result, profits will start to increase.

Step 3: Increase customer contact. After making these structural improvements (focusing on customers and moving resources near them), differentiated organisations can then use the customer knowledge and relationships, and process speed and flexibility they have developed to start improving their processes. First, they should increase the level of contact with their customers (especially face-to-face) to help them better understand which processes add most value and 
identify areas for improvement. This will enable them to further improve the quality of their services. Profit will also increase as customers are prepared to pay a higher price for these services. However, the success of this action depends on how motivated customers are to give feedback, which is why the relationships with them need to be strengthened beforehand.

Step 4: Increase process flexibility. As the organisations start to better understand their processes, they should then make them more flexible so they can be customised to different needs. The flexibility of the steps that add most value to customers should be increased first as customers are willing to pay more for these improvements. The customer knowledge and relationships developed earlier by focusing managers on customers and increasing customer contact make it easier to identify these steps and predict the impact of changing them.

Step 5: Develop customer knowledge/relationship barriers to entry. Whilst making these structural and process improvements (focusing in customers, moving resources closer to them, increasing customer contact and making processes more flexible), organisations should try to develop unique customer knowledge and relationships that are difficult for their competitors to imitate. If they are able to do this, then customer loyalty and market share will increase. Although customers are usually more loyal in differentiated markets than low cost ones, these barriers still need to be sustained after they have been built. A firm's ability to achieve and sustain these barriers depends on the strength of relationships it has developed, stability of the market it serves and the activities of its competitors. For example, if customers frequently change roles or organisations then the customer knowledge it has developed will quickly become out of date and new relationships will need to be built. Therefore, it is important to keep close to customers and identify these changes before they occur so they can be carefully managed. Equally, it is also important to monitor the customer 
knowledge and relationships of its competitors, and developments in other industries (such as new service technologies) that could potentially be adopted by their competitors and eliminate their competitive advantage.

Step 6: Develop unique services. Once these entry barriers are in place, then differentiated organisations should start using their customer and service knowledge to develop unique services that are difficult for competitors to imitate. This will further increase the loyalty and profitability of their customers. To do this, they must continually collate, review and understand the customer knowledge they have to identify current needs that are not being met and predict future ones that might develop. Needs that customers might not even realise they currently have, or may have in the future. It will be easier to stay ahead of their competitors if they can develop services that create new needs and behaviours rather than simply serving existing ones.

\section{Conclusion}

This paper presents thirteen propositions about how service internal fit impacts business performance in low cost and differentiated markets. It then uses these relationships to develop two 'fitness ladder' frameworks to help practitioners serving low cost or differentiated markets better understand how to improve internal fit, the impact each change will have and the factors affecting this impact.

However, practitioners should be cautious when applying these findings as our research has some limitations. First, we only studied the impact of fourteen internal fit variables on seven performance variables. Although this is more comprehensive than previous studies, there may be significant 
factors that have not been considered. Second, although significant internal fit-performance relationships were identified by comparing the seven year journeys across all eleven SBUs with statistical relationships based on their current internal fit and performance levels, it is not absolutely certain that the changes in performance were a direct result of the internal fit improvements they made. For example, external factors or other changes made during the same period may have improved performance or performance may simply have been given more attention than before (Roethlisberger and Dickson, 1934). Third, although our observations are based on findings from organisations operating in a wide range of industries (banking, communications, construction, emergency response, engineering, retail and utility), they may not generalise to other organisations, settings and environments.

Despite these limitations, the findings presented here offer more clarity than previous research about how internal fit might impact performance of organisations serving low cost or differentiated markets. They also support previous research findings that creating fit is more important in improving performance than a firm's overall choice of strategy (Smith and Reece, 1999) and help answer the call for a deeper understanding of the strategic fit-performance relationship (Hill and Brown, 2007; da Silveira and Sousa, 2010; Hill and Cuthbertson, 2011).

Future longitudinal, market-specific research can now build on this work by testing the propositions developed on a larger sample of organisations. We found these relationships depended on market needs, but it would also be useful to understand the impact of other market factors such as level and type of competition, stability of demand and needs, or accessibility to new markets, customers and resources. Also, is there a 'best' sequence for improving internal fit? Our findings suggest there is, but this needs to be better understood. For example, how does focusing managers on customers in 
firms serving differentiated markets affect the performance impact of further fit improvements? And what is the impact of 'jumping' a step in the 'fitness ladder'? Or can the benefit that each step creates be replicated by other strategic decisions that have not considered?

This study also looked at how organisations improved performance over a seven year period, but it would be useful to also analyse ones where performance decreased to better understand what factors caused this decline. Equally, it would be interesting to know how firms can maintain 'high performance' once they have achieved it. For example, which factors should be kept stable and which should be intentionally disrupted and changed so they can stay ahead of their competitors. 


\section{Acknowledgements}

We would like to thank the 257 executives interviewed who have asked to remain anonymous to protect the identity of the organisations researched. They all committed significant time and effort to the project by providing data and information about the firms in which they worked, enabling us to observe how the they operated, giving us access to documents and letting us test the emerging fitperformance relationships from the research against their knowledge, insight and experience. In particular, we wish to thank the 14 executives who formed part of the research steering group.

This paper has also been significantly guided and improved by the comments and suggestions from a number of academics such as Professors Kunal Basu, Keith Blois, Terry Hill, Jonathan Reynolds and David Upton. 


\section{References}

Ahmad, S. and Schroeder, R.G. (2003), "The impact of human resource management practices on operational performance: Recognizing country and industry differences", Journal of Operations Management, Vol. 21 No. 1, pp. 19-43.

Anand, G. and Ward, P.T. (2004), "Fit, flexibility and performance in manufacturing: Coping with dynamic environments", Production and Operations Management, Vol. 13 No. 4, pp. 369-85.

Aranda, D. (2002), "Relationship between operations strategy and size in engineering consulting firms”, International Journal of Service Industry Management, Vol. 13 No. 3, pp. 263-285.

Boyer, K.K., Leong, G.K., Ward, P.T., Krajewski, L.J. (1997), "Unlocking the potential of advanced manufacturing technologies", Journal of Operations Management, Vol. 15 No. 4, pp. 331347.

Boyer. K.K. and McDermott. C. (1999), "Strategic consensus in operations strategy", Journal of Operations Management, Vol. 17 No. 3, pp. 289-305.

Boyer, K., Swink, M., Rosenzweig, E. (2005), "Operations strategy research in the POMS journal”, Production and Operations Management, Vol. 14 No. 4, pp. 442-449.

Chase, R. and Hayes, R. (1991), "Beefing up operations in service firms", Sloan Management Review, Fall, pp. 15-26.

Chenhall, R.H. and Langfield-Smith, K. (2007), "Multiple perspectives of performance measures", European Management Journal, Vol. 25 No. 4, pp. 266-282.

Choe, K., Booth, D. and Hu, M. (1997), "Production competence and its impact on business performance", Journal of Manufacturing Systems, Vol. 16 No. 6, pp. 409-421.

Denrell, J., Fang, C. and Zhao, Z. (2013), "Inferring superior capabilities from sustained superior performance: A bayesian analysis”, Strategic Management Journal, Vol. 34, pp. 182-196. 
Eisenhardt. K.M. (1989), "Building theories from case study research”, Academy of Management Review, Vol. 14 No. 4, pp. 532-550.

Eisenhardt, K.M. and Graebner, M.E. (2007), “Theory building from cases: opportunities and challenges", Academy of Management Journal, Vol. 50 No. 1, pp. 25-32.

Ferdows, K. and DeMeyer, A. (1990), "Lasting improvements in manufacturing capabilities: in search of a new theory”, Journal of Operations Management, Vol. 9 No. 2, pp. 168-84.

Ferdows, K. and Thurnheer, F. (2010), "Building factory fitness", International Journal of Operations and Production Management, Vol. 31 No. 9, pp. 916-934.

Heskett. J.L. (1986), “Managing in the service economy. HBS Press. Boston, MA.

Hill. A.J. and Brown. S. (2007), "Strategic profiling: A visual representation of internal strategic fit in service organisations", International Journal of Operations and Production Management, Vol. 27 No. 12, pp. 1333-1361.

Hill, A.J. and Cuthbertson, R. (2011), "Fitness map: A classification of internal strategic fit in service organisations", International Journal of Operations and Production Management, Vol. 31 No. 9, pp. 991-1020.

Hill, A.J. and Hill, T.J. (2012), “Operations management”, $3^{\text {rd }}$ Edition. Macmillan. London.

Kaplan, R.S. and Norton, D.P. (1992), "The balance scorecard - measures that drive performance”, Harvard Business Review, Vol. 69, pp. 71-79.

Kathuria. R. and Davis. E.B. (2001), "Quality and work force management practices: The managerial performance implications", Production and Operations Management, Vol. 10 No. 4, pp. 460-477.

Ketokivi, M. and Choi, T. (2014), "Renaissance of case research as a scientific method", Journal of Operations Management, Vol. 32 No. 5, pp. 232-240.

Ketokivi, M. and Schroeder, R. (2004), "Manufacturing practices, strategic fit and performance: a 
routine-based view”, International Journal of Operations and Production Management, Vol. 24 No. 2, pp. 171-191.

Kellogg, D.L. and Nie, W. (1995), “A framework for strategic service management”, Journal of Operations Management, Vol. 13, pp. 323-337.

Kotha, S. and Swamidass, P.M. (2000), "Strategy, advantaged manufacturing technology and performance: Empirical evidence from US manufacturing firms", Journal of Operations Management, Vol. 18 No. 3, pp. 297-313.

Lillis, B., and Sweeney, M. (2013), "Managing the fit between the views of competitive strategy and the strategic role of service operations", European Management Journal, Vol. 31 No. 6, pp. 564-590.

Lindman, F.T., Callarman, T.E., Fowler, K.L. and McClatchey, C.A. (2001), "Strategic consensus and manufacturing performance", Journal of Managerial Issues, Vol. 13 No. 1, p. 45.

Menda, R. and Dilts, D. (1997), “The manufacturing strategy formulation process: Linking multifunctional viewpoints”, Journal of Operations Management, Vol. 15 No. 4, pp. 223-241.

Meredith, J. (1998), "Building operations management theory through case and field research", Journal of Operations Management, Vol. 16 No. 4, pp. 441-454.

Miller, J.G. (1981), "Fit production systems to the task", Harvard Business Review, Vol. 59 No. 1, pp. 145-154.

Mohrman, S.A., Gibson, C.B. and Mohrman, A.M. (2001), "Doing research that is useful to practice: A model and empirical exploration, Academy of Management Journal, Vol. 44 No. 2, pp. 357-375.

Naman, J.L. and Slevin, D.P. (1993), "Entrepreneurship and the concept of fit: a model and empirical tests", Strategic Management Journal, Vol. 14 No. 2, pp. 137-153. 
Papke-Shields. K.E. and Malhotra. M.K. (2001), “Assessing the impact of the manufacturing executive's role on business performance through strategic alignment", Journal of Operations Management, Vol. 19 No. 1, pp. 5-22.

Parthasarthy, R. and Sethi, S.P. (1992), “The Impact of Flexible Automation on Business Strategy and Organizational Structure", The Academy of Management Review, Vol. 17 No. 1, pp. 86-112.

Prajogo, D.I. (2016), 'The strategic fit between innovation strategies and business environment in delivering business performance", International Journal of Production Economics, Vol. 171, pp. 241-249.

Ramanujam, V. and Venkatraman, N. (1987), "Planning system characteristics and planning effectiveness", Strategic Management Journal, Vol. 8 No. 5, pp. 453-469.

Rhee, M, and Mehra, S. (2006), "A strategic review of operations and marketing functions in retail banks", International Journal of Service Industry Management, Vol. 17 No. 4, pp. 364-379.

Robinson. A.G. and Stern. S. (1998), “Corporate creativity: How innovations and improvement actually happen”, Berrett-Koehler Publishers. San Francisco. CA.

Roethlisberger, F.J., Dickson, W.J. (1934), "Management and the Worker", Harvard University, Boston.

Roth, A.V. and Menor, L.J. (2003), "Insights into service operations management: A research agenda", Production and Operations Management, Vol. 12 No. 2, pp. 145-165.

Safizadeh, M.H., Ritzman. L.P., Sharma. D. and Wood. C. (1996), “An empirical analysis of the product-process matrix”, Management Science, Vol. 42 No. 11, pp. 1576-1591. 
Sardana, D., Terziovski, M. and Gupta, N. (2016), "The impact of strategic alignment and responsiveness to market on manufacturing firm's performance", International Journal of Production Economics, Vol. 177, pp. 131-138.

da Silveira, G. (2005), "Market priorities, manufacturing configuration, and business performance: an empirical analysis of the order-winners framework", Journal of Operations Management, Vol. 23 No. 6, pp. 662-675.

da Silveira, G. and Sousa, R. (2010), "Paradigms of choice in manufacturing strategy: Exploring performance relationships of fit, best practices and capability-based approaches", International Journal of Operations and Production Management, Vol. 30 No. 12, pp. 1219-1245.

Smith. T.M. and Reece. J.S. (1999), “The relationship of strategy, fit, productivity and business performance in a service setting”, Journal of Operations Management, Vol. 17 No. 2, pp. 145-161.

Sousa, R. and Voss, C.A. (2008), “Contingency research in operations management practices", Journal of Operations Management, Vol. 26, pp. 697-713.

Stepanovich, P.L. and Mueller, J.D. (2002), "Mapping Strategic Consensus”, Journal of Business and Management, Vol. 8 No. 2, pp. 147-164.

Strauss, A.L. and Corbin, J.M. (1990), "Basics of Qualitative Research: Grounded Theory Procedures and Techniques", Sage Publications, Newbury Park, CA.

Swamidass, P.M., Newell, W.T. (1987), "Manufacturing strategy, environmental uncertainty and performance: a path analytic model”, Management Science, Vol. 33 No. 4, pp.509-525.

Van Dierdonck. R. and Miller. J.G. (1980), "Designing production planning and control systems", Journal of Operations Management, Vol. 1 No. 1, pp. 37-46. 
Venkatraman. N. (1989), “The concept of fit in strategy research: Toward verbal and statistical correspondence", Academy of Management Review, Vol. 14 No. 3, pp. 423-444.

Vickery, S.K., Droge, C., Markland, R.E. (1993), "Production competence and business strategy: do they affect business performance”, Decision Sciences, Vol. 24 No. 2, pp. 435-455.

Voss, C. Tsikriktsis, N. and Frohlich, M. (2002), "Case research in operations management", International Journal of Operations and Production Management, Vol. 22 No. 2, pp. 195-219.

Voss, C., Roth, A. and Chase, R. (2008), "Experience, service operations strategy, and services as destinations: foundations and exploratory investigation", Production and Operations Management, Vol. 17 No. 3, pp. 247-66.

Wacker, J.G. (1998), “A definition of theory: Research guidelines for different theory-building research methods in operations management”, Journal of Operations Management, Vol. 16, pp. 361-385.

Ward, P.T., Leong, G.K., Boyer, K.K. (1994), "Manufacturing proactiveness and performance", Decision Sciences, Vol. 25 No. 3, pp. 337-359.

Weick, K.E. (2007), “The generative properties of richness”, Academy of Management Journal, Vol. 50 No. 1, pp. 14-35.

Yin, R.K. (1994), “Case study research: Design and methods”, 2 $2^{\text {nd }}$ edition. Sage.

Yip, G.S., Deviancy, T.M. and Johnson, G. (2009), "Measuring long term superior performance: The UK's long-term superior performers 1984-2003”, Long Range Planning, Vol. 42, pp. $390-413$.

Youndt. M.A.. Snell. S.A.. Dean Jr.. J.W. and Lepak. D.P. (1996), "Human resource management, manufacturing strategy and firm performance", Academy of Management Journal, Vol. 39 No. 4, pp. 836-866. 
Table 1

Empirical research investigating the impact of fit on business performance (1980 - 2016)

\begin{tabular}{|c|c|c|c|c|c|c|c|c|}
\hline \multirow[t]{3}{*}{ Firm and fit type } & \multicolumn{5}{|l|}{ Fit variables } & \multicolumn{3}{|c|}{ Business performance variables } \\
\hline & \multirow[t]{2}{*}{ Market } & \multirow{2}{*}{$\begin{array}{l}\text { Business } \\
\text { strategy }\end{array}$} & \multicolumn{3}{|c|}{ Operations strategy } & \multirow[t]{2}{*}{ Operational } & \multirow[t]{2}{*}{ Financial } & \multirow{2}{*}{$\begin{array}{l}\text { Compet- } \\
\text { itiveness }\end{array}$} \\
\hline & & & Structures & Systems & Processes & & & \\
\hline \multicolumn{9}{|l|}{ Service external fit } \\
\hline $\begin{array}{l}\text { Smith and } \\
\text { Reece } \\
(1999)\end{array}$ & $\begin{array}{l}\text { Customer } \\
\text { selection }\end{array}$ & $\begin{array}{l}\text { Competitive } \\
\text { strategy }\end{array}$ & $\begin{array}{c}\text { Location of } \\
\text { operation }\end{array}$ & $\begin{array}{l}\text { Management style } \\
\text { Human resource } \\
\text { practices }\end{array}$ & - & Cost & Profit & - \\
\hline $\begin{array}{l}\text { Rhee and } \\
\text { Mehra } \\
(2006)\end{array}$ & - & $\begin{array}{l}\text { Strategic } \\
\text { approach }\end{array}$ & $\begin{array}{l}\text { Operational } \\
\text { integration }\end{array}$ & $\begin{array}{l}\text { Capacity management } \\
\text { Facility management }\end{array}$ & $\begin{array}{l}\text { Encounter } \\
\text { management }\end{array}$ & - & $\begin{array}{l}\text { Profit } \\
\text { Sales } \\
\text { Return on } \\
\quad \text { equity }\end{array}$ & - \\
\hline \multicolumn{9}{|c|}{ Manufacturing external fit } \\
\hline $\begin{array}{l}\text { Van } \\
\text { Dierdonck } \\
\text { et al (1980) }\end{array}$ & $\begin{array}{l}\text { Strategic } \\
\text { task }\end{array}$ & $\begin{array}{l}\text { Competitive } \\
\text { strategy }\end{array}$ & - & - & $\begin{array}{l}\text { Investment } \\
\text { Integrativeness }\end{array}$ & - & $\begin{array}{l}\text { Profit } \\
\text { Sales growth }\end{array}$ & - \\
\hline Miller (1981) & - & $\begin{array}{l}\text { Company } \\
\text { goals }\end{array}$ & $\begin{array}{l}\text { Management } \\
\text { structure }\end{array}$ & - & Process choice & - & - & - \\
\hline $\begin{array}{l}\text { Parthasarthy } \\
\text { and Sethi } \\
\text { (1992) }\end{array}$ & - & $\begin{array}{l}\text { Competitive } \\
\text { strategy } \\
\text { Organisational } \\
\text { structure }\end{array}$ & $\begin{array}{l}\text { Management } \\
\text { structure }\end{array}$ & - & $\begin{array}{l}\text { Process } \\
\text { flexibility }\end{array}$ & - & $\begin{array}{l}\text { Sales growth } \\
\text { Return on } \\
\text { investment }\end{array}$ & - \\
\hline $\begin{array}{l}\text { Lindman et al. } \\
\text { (2001) }\end{array}$ & $\begin{array}{l}\text { Performance } \\
\text { objectives } \\
\text { Stage in } \\
\text { product } \\
\text { lifecycle }\end{array}$ & $\begin{array}{l}\text { Competitive } \\
\text { strategy }\end{array}$ & - & - & $\begin{array}{l}\text { Process choice } \\
\text { Process } \\
\text { flexibility }\end{array}$ & $\begin{array}{l}\text { Cost } \\
\text { Flexibility } \\
\text { Quality } \\
\text { Reliability }\end{array}$ & - & - \\
\hline $\begin{array}{l}\text { Papke-Shields } \\
\text { et al. (2001) }\end{array}$ & - & $\begin{array}{l}\text { Company } \\
\text { goals }\end{array}$ & - & $\begin{array}{l}\text { Goals } \\
\text { Support for goals } \\
\text { Strategic influence }\end{array}$ & - & - & $\begin{array}{l}\text { Sales growth } \\
\text { Earnings } \\
\text { growth } \\
\text { Profit }\end{array}$ & $\begin{array}{r}\text { Market } \\
\text { share }\end{array}$ \\
\hline $\begin{array}{l}\text { Prajogo } \\
(2016)\end{array}$ & $\begin{array}{l}\text { Dynamism } \\
\text { Competition }\end{array}$ & - & - & - & $\begin{array}{l}\text { Process } \\
\text { flexibility }\end{array}$ & - & $\begin{array}{l}\text { Sales growth } \\
\text { Profit }\end{array}$ & $\begin{array}{r}\text { Market } \\
\text { share }\end{array}$ \\
\hline $\begin{array}{r}\text { Sardana } \\
(2016)\end{array}$ & - & $\begin{array}{l}\text { Company } \\
\text { goals }\end{array}$ & - & - & Process choice & $\begin{array}{l}\text { Cost } \\
\text { Delivery }\end{array}$ & $\begin{array}{l}\text { Sales growth } \\
\text { Profit }\end{array}$ & $\begin{array}{c}\text { Market } \\
\text { share }\end{array}$ \\
\hline \multicolumn{9}{|c|}{ Manufacturing internal fit } \\
\hline $\begin{array}{c}\text { Safizadeh et } \\
\text { al. (1996) }\end{array}$ & $\begin{array}{c}\text { Performance } \\
\text { objectives }\end{array}$ & - & - & - & Process choice & $\begin{array}{l}\text { Cost } \\
\text { Flexibility } \\
\text { Quality } \\
\text { Speed } \\
\text { Reliability } \\
\text { Design }\end{array}$ & - & - \\
\hline $\begin{array}{l}\text { Youndt et al. } \\
\text { (1996) }\end{array}$ & $\begin{array}{c}\text { Performance } \\
\text { objectives }\end{array}$ & - & - & Management practices & - & $\begin{array}{l}\text { Cost } \\
\text { Quality } \\
\text { Speed } \\
\text { Reliability } \\
\text { Morale } \\
\text { Inventory }\end{array}$ & - & - \\
\hline $\begin{array}{l}\text { Kathuria and } \\
\text { Davis } \\
(2001)\end{array}$ & $\begin{array}{c}\text { Performance } \\
\text { objectives }\end{array}$ & - & - & Management practices & - & $\begin{array}{l}\text { Cost } \\
\text { Quality } \\
\text { Reliability }\end{array}$ & - & - \\
\hline $\begin{array}{l}\text { Anand and } \\
\text { Ward (2004) }\end{array}$ & $\begin{array}{l}\text { Market } \\
\text { dynamism }\end{array}$ & - & - & - & $\begin{array}{l}\text { Process } \\
\text { flexibility }\end{array}$ & - & Sales growth & $\begin{array}{c}\text { Market } \\
\text { share }\end{array}$ \\
\hline $\begin{array}{l}\text { Ketokivi and } \\
\text { Schroeder } \\
(2004)\end{array}$ & $\begin{array}{c}\text { Performance } \\
\text { objectives }\end{array}$ & - & - & Management practices & - & $\begin{array}{l}\text { Cost } \\
\text { Flexibility } \\
\text { Quality } \\
\text { Speed }\end{array}$ & - & - \\
\hline $\begin{array}{l}\text { da Silveira } \\
\text { (2005) }\end{array}$ & $\begin{array}{l}\text { Competitive } \\
\text { criteria }\end{array}$ & - & $\begin{array}{l}\text { Capital } \\
\text { investment }\end{array}$ & - & $\begin{array}{l}\text { Process choice } \\
\text { Inventory }\end{array}$ & - & $\begin{array}{l}\text { Profit } \\
\text { Return on } \\
\quad \text { investment }\end{array}$ & $\begin{array}{c}\text { Market } \\
\text { share }\end{array}$ \\
\hline $\begin{array}{l}\text { da Silveira } \\
\text { and Sousa } \\
(2010)\end{array}$ & - & - & $\begin{array}{l}\text { Management } \\
\text { structure } \\
\text { Capital } \\
\text { investment }\end{array}$ & - & $\begin{array}{l}\text { Process choice } \\
\text { Automation } \\
\text { Inventory }\end{array}$ & $\begin{array}{l}\text { Cost } \\
\text { Quality } \\
\text { Reliability } \\
\text { Flexibility }\end{array}$ & - & - \\
\hline $\begin{array}{l}\text { Ferdows and } \\
\text { Thurnheer } \\
(2010)\end{array}$ & $\begin{array}{c}\text { Performance } \\
\text { objectives }\end{array}$ & & - & Management practices & Process choice & $\begin{array}{l}\text { Cost } \\
\text { Safety } \\
\text { Speed }\end{array}$ & - & - \\
\hline
\end{tabular}




\section{Table 2}

Significant positive and negative fit and performance relationships identified by the empirical research shown in Table 1

\begin{tabular}{|c|c|c|c|c|c|}
\hline \multicolumn{2}{|c|}{$\begin{array}{l}\text { Fit between variables } \\
\text { (grouped by firm and fit type) }\end{array}$} & \multicolumn{3}{|c|}{ Positive performance relationships } & \multirow{2}{*}{$\begin{array}{l}\text { Negative } \\
\text { operational } \\
\text { performance } \\
\text { relationship }\end{array}$} \\
\hline (grouped by firm and fit ty & pe) & \multicolumn{2}{|c|}{ Operational Financial } & \multirow[t]{2}{*}{ Competitiveness } & \\
\hline \multicolumn{5}{|l|}{ Service external fit } & \\
\hline Operations strategy & and business strategy & - & $\begin{array}{l}\text { Smith and Reece (1999) } \\
\text { Rhee and Mehra (2006) }\end{array}$ & - & - \\
\hline \multicolumn{6}{|c|}{ Manufacturing external fit } \\
\hline Operations strategy & and business strategy & $\begin{array}{l}\text { Lindman et } \\
\text { al. }(2001)\end{array}$ & - & - & - \\
\hline \multirow{5}{*}{ Process flexibility } & and competitive strategy & - & $\begin{array}{l}\text { Van Dierdonck et al. } \\
\text { (1980) }\end{array}$ & - & - \\
\hline & and company goals & - & $\begin{array}{l}\text { Miller (1981) } \\
\text { Papke-Shields et al. } \\
\quad(2001) \\
\text { Sardana (2016) }\end{array}$ & Sardana (2016) & - \\
\hline & and business strategy & - & $\begin{array}{l}\text { Parthasarthy and Sethi } \\
\text { (1992) }\end{array}$ & - & - \\
\hline & and market dynamism & - & $\begin{array}{l}\text { Anand and Ward (2004) } \\
\text { Prajogo (2016) }\end{array}$ & - & - \\
\hline & $\begin{array}{l}\text { and organisational } \\
\text { structure }\end{array}$ & - & $\begin{array}{l}\text { Parthasarthy and Sethi } \\
\text { (1992) }\end{array}$ & - & - \\
\hline \multicolumn{6}{|c|}{ Manufacturing internal fit } \\
\hline \multirow[t]{2}{*}{ Performance objectives } & and process choice & $\begin{array}{l}\text { Ferdows and } \\
\text { Thurnheer } \\
(2010)\end{array}$ & Safizadeh et al. (1996) & - & - \\
\hline & $\begin{array}{l}\text { and management } \\
\text { practices }\end{array}$ & $\begin{array}{l}\text { Ferdows and } \\
\text { Thurnheer } \\
(2010)\end{array}$ & $\begin{array}{l}\text { Youndt et al. (1996) } \\
\text { Kathuria and Davis } \\
(2001) \\
\text { Ketokivi and Schroeder } \\
(2004)\end{array}$ & - & - \\
\hline Management structure & and process choice & - & - & - & $\begin{array}{r}\text { da Silveira and } \\
\text { Sousa (2010) }\end{array}$ \\
\hline
\end{tabular}


Table 3

Measuring internal fit

\begin{tabular}{|c|c|c|c|c|c|c|c|}
\hline \multirow[t]{2}{*}{ Variable } & \multicolumn{7}{|c|}{ Service operations strategy frameworks } \\
\hline & $\begin{array}{l}\text { Heskett } \\
\text { (1986) }\end{array}$ & $\begin{array}{l}\text { Chase } \\
\text { and } \\
\text { Hayes } \\
(1991)\end{array}$ & $\begin{array}{l}\text { Kellogg } \\
\text { and Nie } \\
\text { (1995) }\end{array}$ & $\begin{array}{l}\text { Aranda } \\
(2002)\end{array}$ & $\begin{array}{l}\text { Roth } \\
\text { and } \\
\text { Menor } \\
\text { (2003) }\end{array}$ & $\begin{array}{l}\text { Hill and } \\
\text { Brown } \\
(2007)\end{array}$ & $\begin{array}{l}\text { Voss et al. } \\
\text { (2008) }\end{array}$ \\
\hline \multicolumn{8}{|l|}{ Market needs } \\
\hline How are orders won? & • & & - & - & & - & - \\
\hline Customer order volume & & & & & & $\bullet$ & \\
\hline \multicolumn{8}{|l|}{ Structures } \\
\hline Organisational centralisation & $\bullet$ & & $\bullet$ & • & • & • & • \\
\hline Management structure & $\bullet$ & - & & & $\bullet$ & $\bullet$ & $\bullet$ \\
\hline \multicolumn{8}{|l|}{ Systems } \\
\hline Performance measures & $\bullet$ & & & & $\bullet$ & $\bullet$ & \\
\hline Employee rewards and developments & $\bullet$ & & & $\bullet$ & $\bullet$ & $\bullet$ & $\bullet$ \\
\hline Quality management & $\bullet$ & $\bullet$ & & & & - & \\
\hline Capacity management & $\bullet$ & & - & - & $\bullet$ & & \\
\hline \multicolumn{8}{|l|}{ Processes } \\
\hline Flexibility & & & & $\bullet$ & $\bullet$ & $\bullet$ & \\
\hline Automation & - & - & • & $\bullet$ & $\bullet$ & - & - \\
\hline Level of customer contact & & $\bullet$ & & & $\bullet$ & $\bullet$ & $\bullet$ \\
\hline Type of customer contact & & $\bullet$ & & $\bullet$ & $\bullet$ & & \\
\hline \multicolumn{8}{|l|}{ Competitive advantage } \\
\hline Barriers to entry & - & & & & & • & \\
\hline Service differentiation & - & & & & & - & \\
\hline
\end{tabular}




\section{Table 4}

\section{Case study characteristics}

\begin{tabular}{|c|c|c|}
\hline \multicolumn{2}{|c|}{$\begin{array}{l}\text { Case studies grouped by performance } \\
\text { and market needs }\end{array}$} & Services delivered \\
\hline \multicolumn{3}{|c|}{ Low performing } \\
\hline \multicolumn{3}{|c|}{ Low cost market } \\
\hline 1 & Domestic Utility Provider & Supply gas and electricity to consumers \\
\hline 2 & Construction Service & $\begin{array}{l}\text { Install gas and electricity into existing and new properties for building } \\
\text { developers }\end{array}$ \\
\hline \multicolumn{3}{|c|}{ Differentiated market } \\
\hline 3 & Small-sized Retail Group & Supply broad range of consumer goods \\
\hline 4 & Large Business Utility Provider & Supply gas and electricity to large businesses \\
\hline 5 & Small Business Utility Provider & Supply gas and electricity to small businesses \\
\hline \multicolumn{3}{|c|}{ High performing } \\
\hline \multicolumn{3}{|c|}{ Low cost market } \\
\hline 6 & Communications Group & Support communication needs of consumers and businesses \\
\hline 7 & Large-sized Retail Group & Supply broad range of consumer goods \\
\hline 8 & Emergency Response Service & $\begin{array}{l}\text { Respond to emergency calls from consumers and businesses by sending an } \\
\text { engineer to their property to 'make it safe' within } 30 \text { minutes }\end{array}$ \\
\hline 9 & Utility Metering Service & Install, monitor and service utility meters for consumers and businesses \\
\hline \multicolumn{3}{|c|}{ Differentiated market } \\
\hline & Medium-sized Retail Group & Supply broad range of consumer goods \\
\hline & Product Developer & $\begin{array}{l}\text { Work with businesses to understand their needs and develop new products/ } \\
\text { services to support them }\end{array}$ \\
\hline
\end{tabular}

Note: 'High performing' organisations have greater return on sales and domestic market share than their competitors as shown in Figure 2. 
Table 5

Identifying the internal fit and performance journey in each case study

\begin{tabular}{|c|c|}
\hline Step & Summary \\
\hline $\begin{array}{l}\text { 1. Identified } \\
\text { performance } \\
\text { journey }\end{array}$ & $\begin{array}{l}\text { Identified performance trends over the last seven years relative to competitors through: } \\
\text { - Interviews - with executives (from different functions and levels within the SBU) } \\
\text { - Documents - SBU performance (industry reports and/or those commissioned by the SBU) and } \\
\text { competitor performance (industry reports and/or those commissioned by the SBU) } \\
\text { - Archival records - SBU performance (financial accounts, management reports, historical } \\
\text { performance against plans and targets and/or other reports), and competitor performance } \\
\text { (published results, industry reports and/or those commissioned by the SBU) }\end{array}$ \\
\hline $\begin{array}{l}\text { 2. Identified } \\
\text { market needs }\end{array}$ & $\begin{array}{l}\text { Identified the market order-winner and qualifier trends over the last seven years through: } \\
\text { - Interviews - with customers and executives (from different functions and levels within the SBU) } \\
\text { - Observation - of SBU customer behaviour (listening to telephone calls and/or observing face-to- } \\
\text { face contacts) and competitor customer behaviour (observing face-to-face contacts) } \\
\text { - Archival records - market research (industry reports and/or those commissioned by the business } \\
\text { itself), customer surveys (industry reports and/or those commissioned by the business itself), } \\
\text { SBU customer behaviour (order and/or communication history) and competitor customer } \\
\text { behaviour (order and/or communication history, if possible) }\end{array}$ \\
\hline $\begin{array}{l}\text { 3. Identified 'ideal } \\
\text { fit' profile }\end{array}$ & $\begin{array}{l}\text { Based on the market analysis, the 'ideal profile' trend over the last seven years was identified. For } \\
\text { example, the ideal profile would be } 5.0 \text { if customer orders were won solely through 'price' or } 0.0 \text { if } \\
\text { orders were won solely through 'service/product design' }\end{array}$ \\
\hline $\begin{array}{l}\text { 4. Understood } \\
\text { internal fit } \\
\text { journey }\end{array}$ & $\begin{array}{l}\text { Identified the service offering, structures, systems and processes used within the business and how } \\
\text { they have changed over the last seven years through: } \\
\text { - Interviews - with executives (from different functions and levels within the SBU) } \\
\text { - Observation - of meetings (strategy and management), investment (where it had been made), } \\
\text { level of organisational centralisation (back-office and/or front-office layouts), listening to customer } \\
\text { telephone calls, observing front-office operations and/or customer meetings } \\
\text { - Documents - strategy (strategic and investment plans, budget reviews and/or meeting minutes), } \\
\text { management (reports and/or meeting minutes) and human resource (employee rewards and/or } \\
\text { personal development plans) } \\
\text { - Archival records - strategy (implementation reports, documents and/or communications), } \\
\text { management structure (organisational charts and/or functions, roles and responsibilities), level of } \\
\text { organisational centralisation (office and/or geographical layouts), investment (financial budgets, } \\
\text { actual investments and/or training records), management (management reports), human } \\
\text { resource (salaries, bonuses and/or training records), working procedures, office layouts and/or } \\
\text { equipment investment }\end{array}$ \\
\hline $\begin{array}{l}\text { 5. Identified } \\
\text { 'actual fit' profile }\end{array}$ & $\begin{array}{l}\text { Scored each structure, systems and process variable between } 0.0 \text { and } 5.0 \text { using the measures } \\
\text { shown in Appendix } 4 \text { to show internal fit trends over the last seven years }\end{array}$ \\
\hline $\begin{array}{l}\text { 6. Presented } \\
\text { findings back to } \\
\text { SBU }\end{array}$ & $\begin{array}{l}\text { Presented findings back to the executives interviewed to ensure they agreed with the insights } \\
\text { developed and give them the opportunity to recall any new information } \\
\text { Where necessary case studv was updated to clarify facts or include new data }\end{array}$ \\
\hline
\end{tabular}


Table 6

Internal fit and performance journey: Low cost case studies

Internal fit journey in each case study grouped by current performance

Performance impact

Cost Flex- Speed Profit Market ibility share

Low performing
Domestic Utility Provider (Company 1)

1. Type of customer contact - set up regional call centers to reduce face-toface contact

2. Quality management - monitored how quickly answered customer calls and introduced 'standard scripts' to ensure all customers had a similar experience

Construction Service (Company 2)

1. Performance measures - introduced cost reduction performance measures

2. Employees reward and development - linked to new measures

High performing

Communications Group (Company 6)

1. Flexibility - reduced by offering less service options to customers

2. Type of customer contact - set up self-service website

3. Barriers to entry - previous changes meant it had a low cost-base that was difficult for competitors to imitate

4. Performance measures - focused on cost of serving customers

5. Employee reward and development - linked to new measures

Large-sized Retail Group (Company 7)

1. Management structure - set up matrix structure making Product Managers responsible for a key business process across the whole organisation and all the processes required to design and deliver a particular product group

2. Barriers to entry - previous change meant it developed a unique low cost new service/product development capability

3. Performance measures - introduced new measures to further improve new service/product development without increasing costs

4. Employee reward and development - linked to new measures

Emergency Response Service (Company 8)

1. Performance measures - introduced new measures focused on cost reduction and delivery speed

2. Employee reward and development - linked to new measures

3. Organisational centralisation - moved all its back office functions into a central facility supporting its fifteen front office facilities

4. Management structure - set up functional teams in new central facility making them responsible for reducing costs and shortening delivery leadtimes

5. Flexibility - each functional team standardised and consolidated processes in the delivery system they managed

6. Automation - automated 92 per cent of delivery system processes

7. Capacity management - introduced automated system

8. Barriers to entry - previous changes meant it now had a low cost and short lead-time capability that was difficult to imitate

Utility Metering Service (Company 9)

1. Management structure - made managers responsible for all processes in their operation and a key process across the whole organisation

2. Flexibility - reduced by offering less service options to customers

3. Organisational centralisation - set up 'centres of excellence'

4. Automation - automated processes in these new 'centres of excellence'

5. Barriers to entry - it now had a low cost capability was difficult to imitate

6. Managing capacity - introduced automated system in 'centres of excellence' 
Table 7

Internal fit and performance journey: Differentiated case studies

Internal fit journey in each case study grouped by current performance

Performance impact

Flex- Speed Quality Profit Market Custbility

share omer

loyalty

Low performing

Small-sized Retail Group (Company 3)

1. Type of customer contact - increased face-to-face contact in stores

2. Level of customer contact - increased to build customer relationships, understand needs and customise services

3. Flexibility - increased to deliver more customised services

4. Quality management - introduced 'mystery shoppers'

5. Employee reward and development - modified to motivate employees to build customer relationships and improve service levels

6. Performance measures - introduced new measures to identify gaps in current customer relationships and service offerings

Large Business Utility Provider (Company 4)

1. Organisational centralisation - set up dedicated front office facility + and continued using central back office serving all its markets

2. Management structure - set up key account managers to manage customer relationships, understand needs and develop new services

3. Level of customer contact - introduced a 'customer insight' initiative encouraging staff to spend more time with customers

4. Type of customer contact - introduced face-to-face customer visits

5. Quality management - made staff responsible for service quality

Small Business Utility Provider (Company 5)

1. Organisational centralisation - set up dedicated front office facility + and continued using central back office serving all its markets

2. Management structure - set up customer-based teams in the dedicated front office facility to customise services

3. Level of customer contact - increased to build customer relationships, understand needs and customise services

4. Type of customer contact - introduced face-to-face customer visits

High performing

Medium-sized Retail Group (Company 10)

1. Management structure - restructured head office into customer teams to understand customer needs and develop new services

2. Performance measures - introduced new measures to identify gaps in current customer relationships and service offerings

3. Employee reward and development - linked to new measures

4. Organisational centralisation - moved activities from head office to + local retail operations so they could customise them to their local market needs

5. Flexibility - increased to deliver more customised services

6. Level of customer contact - increased in the local retail operations

Product Developer (Company 11)

1. Organisational centralisation - set up separate facility

2. Management structure - set up cross-functional customer-teams in new facility to support existing customers and attract new ones

3. Performance measures - developed customer-specific measures

4. Employee reward and development - linked to new measures

5. Quality management - introduced customer quality meetings

6. Flexibility - increased to deliver more customised services

7. Barriers to entry - had unique customer knowledge and relationship

8. Service differentiation - tailored to specific customer needs

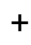

$+\quad+$

$+\quad+$

$\begin{array}{lllll}- & + & & \\ & + & + & + \\ & + & & \\ & & + & + \\ + & + & & +\end{array}$


Table 8

Current performance and internal fit in each case study

\begin{tabular}{|c|c|c|c|c|c|c|c|c|c|c|c|}
\hline \multirow[t]{4}{*}{ Performance and internal fit } & \multicolumn{11}{|c|}{ Case studies grouped by market needs and performance } \\
\hline & \multicolumn{6}{|c|}{ Low cost market } & \multicolumn{5}{|c|}{ Differentiated market } \\
\hline & \multicolumn{2}{|c|}{$\begin{array}{l}\text { Low } \\
\text { performing }\end{array}$} & \multicolumn{4}{|c|}{ High performing } & \multicolumn{3}{|c|}{ Low performing } & \multicolumn{2}{|c|}{$\begin{array}{l}\text { High } \\
\text { performing }\end{array}$} \\
\hline & 1 & 2 & 6 & 7 & 8 & 9 & 3 & 4 & 5 & 10 & 11 \\
\hline \multicolumn{12}{|l|}{ Operational performance } \\
\hline Cost & 0.2 & 1.3 & 2.8 & $3.9^{*}$ & $4.8^{*}$ & $4.1^{*}$ & 1.1 & 1.0 & $3.0^{*}$ & $3.6^{*}$ & 1.0 \\
\hline Flexibility & 1.6 & 0.6 & $3.4^{*}$ & 1.8 & 2.0 & 2.4 & $4.2^{*}$ & 1.6 & 1.9 & $3.8^{*}$ & $4.1^{*}$ \\
\hline Speed & 1.4 & 1.2 & 2.8 & $3.8^{*}$ & $3.9^{*}$ & $3.6^{*}$ & 0.8 & 0.8 & 2.8 & 2.2 & 1.1 \\
\hline Quality & $4.9^{*}$ & 2.0 & 2.2 & $4.2^{*}$ & $4.1^{*}$ & $4.1^{*}$ & $3.9^{*}$ & 1.8 & 2.8 & $4.2^{*}$ & $4.9^{*}$ \\
\hline \multicolumn{12}{|l|}{ Financial performance } \\
\hline Profit & 1.2 & 1.0 & $3.1^{*}$ & $3.1^{*}$ & $4.6^{*}$ & $4.9^{*}$ & 1.5 & 1.6 & 2.4 & $3.4^{*}$ & $4.4^{*}$ \\
\hline \multicolumn{12}{|l|}{ Competitiveness } \\
\hline Market share & 1.1 & 2.1 & $3.0^{*}$ & $4.1^{*}$ & $3.1^{*}$ & $3.1^{*}$ & 1.9 & 2.3 & 1.2 & 4.9* & $3.6^{*}$ \\
\hline Customer loyalty & 0.4 & 0.6 & 1.6 & $3.8^{*}$ & $3.8^{*}$ & 2.2 & 2.2 & 0.2 & 1.8 & $4.6^{*}$ & $4.9^{*}$ \\
\hline \multicolumn{12}{|l|}{ Structural fit } \\
\hline Organisational centralisation & 0.5 & 0.4 & 2.3 & 2.3 & $3.9^{*}$ & $3.9^{*}$ & 0.3 & 2.0 & 2.4 & $4.0^{*}$ & $3.9^{*}$ \\
\hline Management structure & 0.4 & 0.2 & 2.2 & $3.9^{*}$ & $3.9^{*}$ & $4.0^{*}$ & 0.9 & 2.3 & 2.2 & $3.9^{*}$ & $3.9^{*}$ \\
\hline \multicolumn{12}{|l|}{ Systems fit } \\
\hline Performance measures & 1.2 & $3.9^{*}$ & $4.0^{*}$ & $3.9^{*}$ & 2.5 & 1.5 & $3.9^{*}$ & 0.4 & 2.1 & 1.8 & $3.8^{*}$ \\
\hline Employee rewards and developments & 1.4 & $3.9^{*}$ & $4.0^{*}$ & $4.0^{*}$ & $3.1^{*}$ & 1.5 & $3.9^{*}$ & 0.5 & 2.0 & $3.5^{*}$ & $3.1^{*}$ \\
\hline Quality management & 2.5 & 0.3 & 2.3 & 2.5 & $3.2^{*}$ & $3.9^{*}$ & 2.5 & 2.3 & 2.4 & $3.7^{*}$ & $3.1^{*}$ \\
\hline Capacity management & 1.7 & 0.4 & 2.5 & 2.3 & $3.7^{*}$ & $3.9^{*}$ & $4.0^{*}$ & 2.1 & 2.6 & $3.8^{*}$ & $3.1^{*}$ \\
\hline \multicolumn{12}{|l|}{ Process fit } \\
\hline Flexibility & 0.4 & 0.3 & $3.9^{*}$ & 2.0 & $3.9^{*}$ & $3.8^{*}$ & $3.8^{*}$ & 1.1 & 2.3 & $3.7^{*}$ & $3.6^{*}$ \\
\hline Automation & 0.5 & 1.5 & 2.4 & $3.0^{*}$ & $3.5^{*}$ & $3.0^{*}$ & 0.9 & 0.4 & 2.5 & 2.2 & $3.1^{*}$ \\
\hline Level of customer contact & 0.4 & 0.2 & 2.3 & 2.1 & $3.9^{*}$ & $4.0^{*}$ & $3.9^{*}$ & 1.3 & 2.9 & 2.6 & $3.8^{*}$ \\
\hline Type of customer contact & 2.5 & 0.3 & 2.2 & 2.1 & $3.1^{*}$ & 2.3 & $3.9^{*}$ & 2.0 & $3.9^{*}$ & $4.0^{*}$ & $3.8^{*}$ \\
\hline \multicolumn{12}{|l|}{ Competitive advantage fit } \\
\hline Barriers to entry & 1.2 & 1.7 & $3.9^{*}$ & $3.5^{*}$ & $3.1^{*}$ & 2.2 & 1.0 & 0.4 & 2.0 & $3.7^{*}$ & $3.8^{*}$ \\
\hline Service differentiation & 0.3 & 0.4 & 2.4 & 2.3 & 2.9 & 2.9 & 0.9 & 0.4 & 2.4 & 2.9 & $3.6^{*}$ \\
\hline
\end{tabular}

Key:

* indicates high performance or internal fit (3.0 or more). 
Table 9

Internal fit and performance journeys: Low cost case studies

\begin{tabular}{|c|c|c|c|c|c|c|c|c|c|c|c|}
\hline \multirow[t]{3}{*}{ Change in internal fit } & \multicolumn{6}{|c|}{$\begin{array}{l}\text { Order of changes in } \\
\text { each case }\end{array}$} & \multicolumn{5}{|c|}{ Performance impact } \\
\hline & \multicolumn{2}{|c|}{$\begin{array}{l}\text { Low } \\
\text { performing }\end{array}$} & \multicolumn{4}{|c|}{$\begin{array}{l}\text { High } \\
\text { performing }\end{array}$} & \multirow[t]{2}{*}{ Cost } & \multirow[t]{2}{*}{$\begin{array}{l}\text { Flex- } \\
\text { ibility }\end{array}$} & \multirow[t]{2}{*}{ Speed } & \multirow[t]{2}{*}{ Profit } & \multirow[t]{2}{*}{$\begin{array}{l}\text { Market } \\
\text { share }\end{array}$} \\
\hline & 1 & 2 & 6 & 7 & 8 & 9 & & & & & \\
\hline \multicolumn{12}{|l|}{ Structures } \\
\hline $\begin{array}{l}\text { Management structure - focused on } \\
\text { processes }\end{array}$ & & & & 1 & 4 & 1 & - & & & + & + \\
\hline $\begin{array}{l}\text { Organisational centralisation - } \\
\text { centralised resources around processes }\end{array}$ & & & & & 3 & 3 & - & & & + & \\
\hline \multicolumn{12}{|l|}{ Systems } \\
\hline $\begin{array}{l}\text { Performance measures - focused on } \\
\text { cost reduction }\end{array}$ & & 1 & 4 & 3 & 1 & & & & & & \\
\hline $\begin{array}{l}\text { Employee reward and development - } \\
\text { linked to cost reduction }\end{array}$ & & 2 & 5 & 4 & 2 & & & & & & \\
\hline \multicolumn{12}{|l|}{$\begin{array}{l}\text { Quality management - standardised and } 2 \\
\text { automated }\end{array}$} \\
\hline $\begin{array}{l}\text { Capacity management - standardised } \\
\text { and automated }\end{array}$ & & & & & 7 & 6 & & & & & \\
\hline \multicolumn{12}{|l|}{ Processes } \\
\hline Flexibility - reduced flexibility & & & 1 & & 5 & 2 & - & - & & + & \\
\hline Automation - increased automation & & & & & 6 & 4 & - & & - & + & \\
\hline $\begin{array}{l}\text { Type of customer contact - encouraged } \\
\text { self-service and reduced face-to-face }\end{array}$ & 1 & & 2 & & & & & & & & \\
\hline \multicolumn{12}{|l|}{ Competitive advantage } \\
\hline $\begin{array}{l}\text { Barriers to entry - developed unique low } \\
\text { cost capability }\end{array}$ & & & 3 & 2 & 8 & 5 & & & & & + \\
\hline
\end{tabular}

Key:

+ indicates a significant performance increase

- indicates a significant performance decrease 
Table 10

Internal fit and performance journeys: Differentiated case studies

\begin{tabular}{|c|c|c|c|c|c|c|c|c|c|c|c|}
\hline \multirow[t]{3}{*}{ Change in internal fit } & \multicolumn{5}{|c|}{$\begin{array}{l}\text { Order of changes in } \\
\text { each case }\end{array}$} & \multicolumn{6}{|c|}{ Performance impact } \\
\hline & \multicolumn{3}{|c|}{$\begin{array}{l}\text { Low } \\
\text { performing }\end{array}$} & \multicolumn{2}{|c|}{$\begin{array}{l}\text { High } \\
\text { performing }\end{array}$} & \multirow[t]{2}{*}{$\begin{array}{l}\text { Flex- } \\
\text { ibility }\end{array}$} & \multirow[t]{2}{*}{ Speed } & \multirow[t]{2}{*}{ Quality } & \multirow[t]{2}{*}{ Profit } & \multirow[t]{2}{*}{$\begin{array}{l}\text { Market } \\
\text { share }\end{array}$} & \multirow{2}{*}{$\begin{array}{l}\text { Cust- } \\
\text { omer } \\
\text { loyalty }\end{array}$} \\
\hline & 3 & 4 & 5 & 10 & 11 & & & & & & \\
\hline \multicolumn{12}{|l|}{ Structures } \\
\hline $\begin{array}{l}\text { Management structure - focused on } \\
\text { customers }\end{array}$ & & 2 & 2 & 1 & 2 & & & + & + & + & + \\
\hline $\begin{array}{l}\text { Organisational centralisation - } \\
\text { located resources near customers }\end{array}$ & & 1 & 1 & 4 & 1 & + & - & & + & & \\
\hline \multicolumn{12}{|l|}{ Systems } \\
\hline $\begin{array}{l}\text { Performance measures - focused on } \\
\text { service design }\end{array}$ & 6 & & & 2 & 3 & & & & & & \\
\hline $\begin{array}{l}\text { Employee reward and development } \\
\text { - linked to service design }\end{array}$ & 5 & & & 3 & 4 & & & & & & \\
\hline $\begin{array}{l}\text { Quality management - introduced } \\
\text { customer meetings and mystery } \\
\text { shoppers }\end{array}$ & 4 & 5 & & & 5 & & & & & & \\
\hline \multicolumn{12}{|l|}{ Processes } \\
\hline Flexibility - increase flexibility & 3 & & & 5 & 6 & + & & & + & & \\
\hline $\begin{array}{l}\text { Level of customer contact - } \\
\text { increased contact }\end{array}$ & 2 & 3 & 3 & 6 & & & & + & + & & \\
\hline $\begin{array}{l}\text { Type of customer contact - } \\
\text { increased face-to-face contact }\end{array}$ & 1 & 4 & 4 & & & & & & & & \\
\hline \multicolumn{12}{|l|}{ Competitive advantage } \\
\hline $\begin{array}{l}\text { Barriers to entry - developed unique } \\
\text { customer knowledge and relationship }\end{array}$ & & & & & 7 & & & & & + & + \\
\hline $\begin{array}{l}\text { Service differentiation - developed } \\
\text { unique designs tailored to specific } \\
\text { customer needs }\end{array}$ & & & & & 8 & & & + & + & & + \\
\hline
\end{tabular}

Key:

+ indicates a significant performance increase

- indicates a significant performance decrease 
Table 11

Statistical internal fit and performance relationships

\begin{tabular}{|c|c|c|c|c|c|c|c|}
\hline \multirow[t]{3}{*}{ Internal fit variable } & \multicolumn{7}{|c|}{ Performance improvement correlation } \\
\hline & \multicolumn{4}{|c|}{ Operational } & \multirow{2}{*}{$\begin{array}{l}\text { Financial } \\
\text { Profit }\end{array}$} & \multicolumn{2}{|c|}{ Competitiveness } \\
\hline & Cost & Flexibility & Speed & Quality & & $\begin{array}{l}\text { Market } \\
\text { share }\end{array}$ & $\begin{array}{l}\text { Customer } \\
\text { loyalty }\end{array}$ \\
\hline \multicolumn{8}{|l|}{ Structures } \\
\hline Organisational centralisation & 0.621 & 0.334 & 0.548 & 0.668 & **0.921 & 0.694 & 0.719 \\
\hline Management Structure & 0.682 & 0.327 & 0.617 & ${ }^{*} 0.768$ & ${ }^{* *} 0.899$ & ${ }^{*} 0.784$ & *0.783 \\
\hline \multicolumn{8}{|l|}{ Systems } \\
\hline Performance measures & 0.029 & 0.305 & 0.010 & 0.332 & 0.014 & 0.192 & 0.312 \\
\hline Employee reward and development & 0.195 & 0.349 & 0.146 & 0.406 & 0.076 & 0.425 & 0.470 \\
\hline Quality management & 0.380 & 0.738 & 0.257 & 0.741 & 0.621 & 0.445 & 0.605 \\
\hline Capacity management & 0.477 & 0.721 & 0.328 & 0.646 & 0.675 & 0.455 & 0.572 \\
\hline \multicolumn{8}{|l|}{ Processes } \\
\hline Flexibility & 0.511 & *0.789 & 0.388 & 0.742 & $* 0.747$ & 0.567 & 0.670 \\
\hline Automation & ${ }^{* *} 0.798$ & 0.183 & ${ }^{*} 0.771$ & 0.719 & $* * 0.873$ & 0.567 & 0.734 \\
\hline Level of customer contact & 0.495 & 0.663 & 0.358 & $* * 0.824$ & ${ }^{*} 0.747$ & 0.334 & 0.657 \\
\hline Type of customer contact & 0.102 & 0.744 & 0.033 & 0.561 & 0.371 & 0.193 & 0.607 \\
\hline \multicolumn{8}{|l|}{ Competitive advantage } \\
\hline Barriers to entry & 0.517 & 0.415 & 0.544 & 0.568 & 0.686 & *0.764 & ${ }^{*} 0.774$ \\
\hline Service differentiation & 0.691 & 0.476 & 0.655 & $* 0.771$ & $* * 0.920$ & 0.657 & ${ }^{* *} 0.819$ \\
\hline
\end{tabular}

Key:

* Significant to 0.01 (0.746 for sample size of 11$)$

** Significant to 0.005 ( 0.794 for sample size of 11$)$ 
Figure 1

Current case study markets

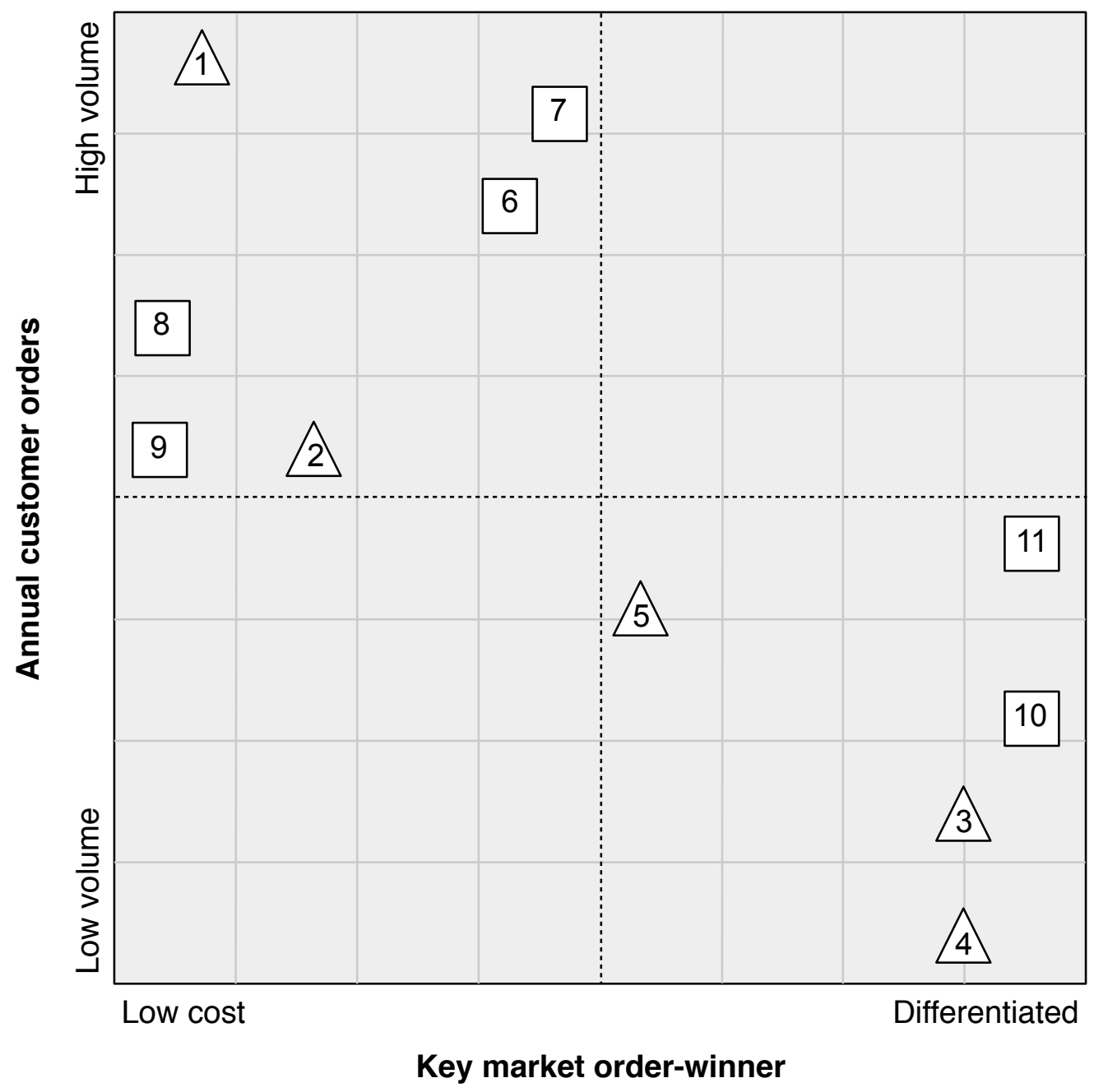

Key

$\triangle$ low performing organisation

$\square$ high performing organisation 
Figure 2

Current case study performance

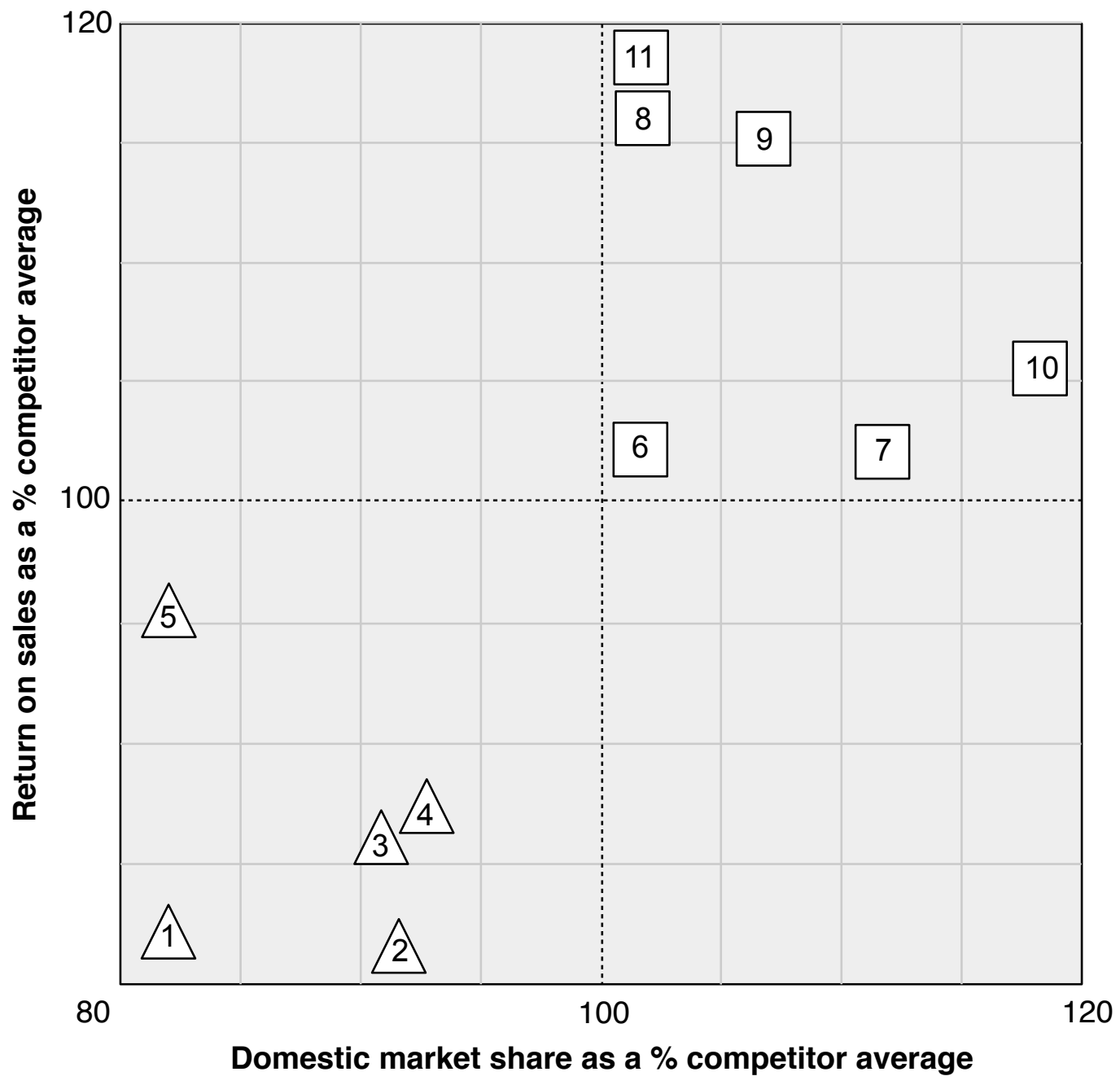

Key

$\triangle$ low performing organization

$\square$ high performing organization 
Figure 3

Low cost fitness ladder

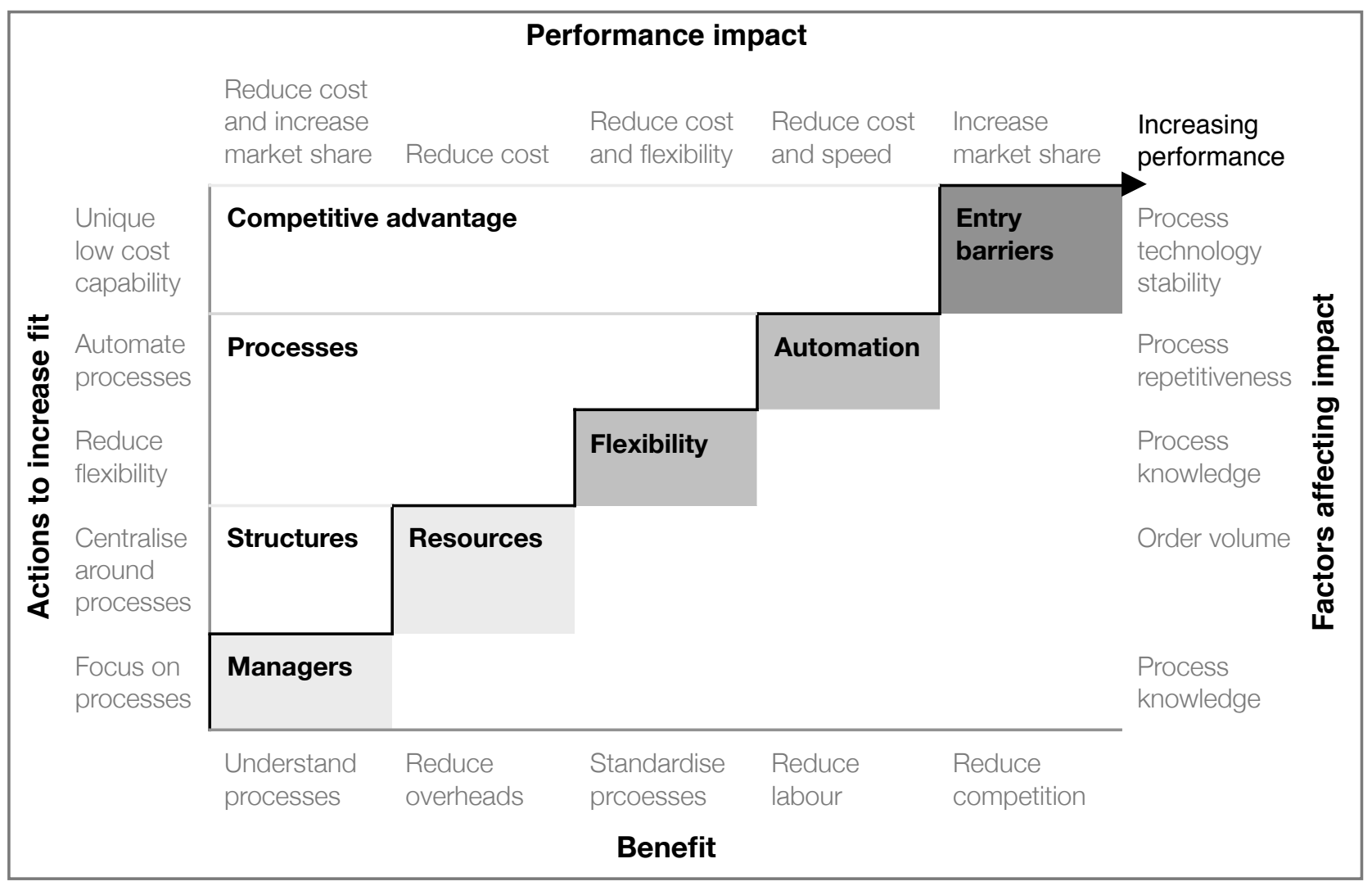


Figure 4

Differentiated fitness ladder

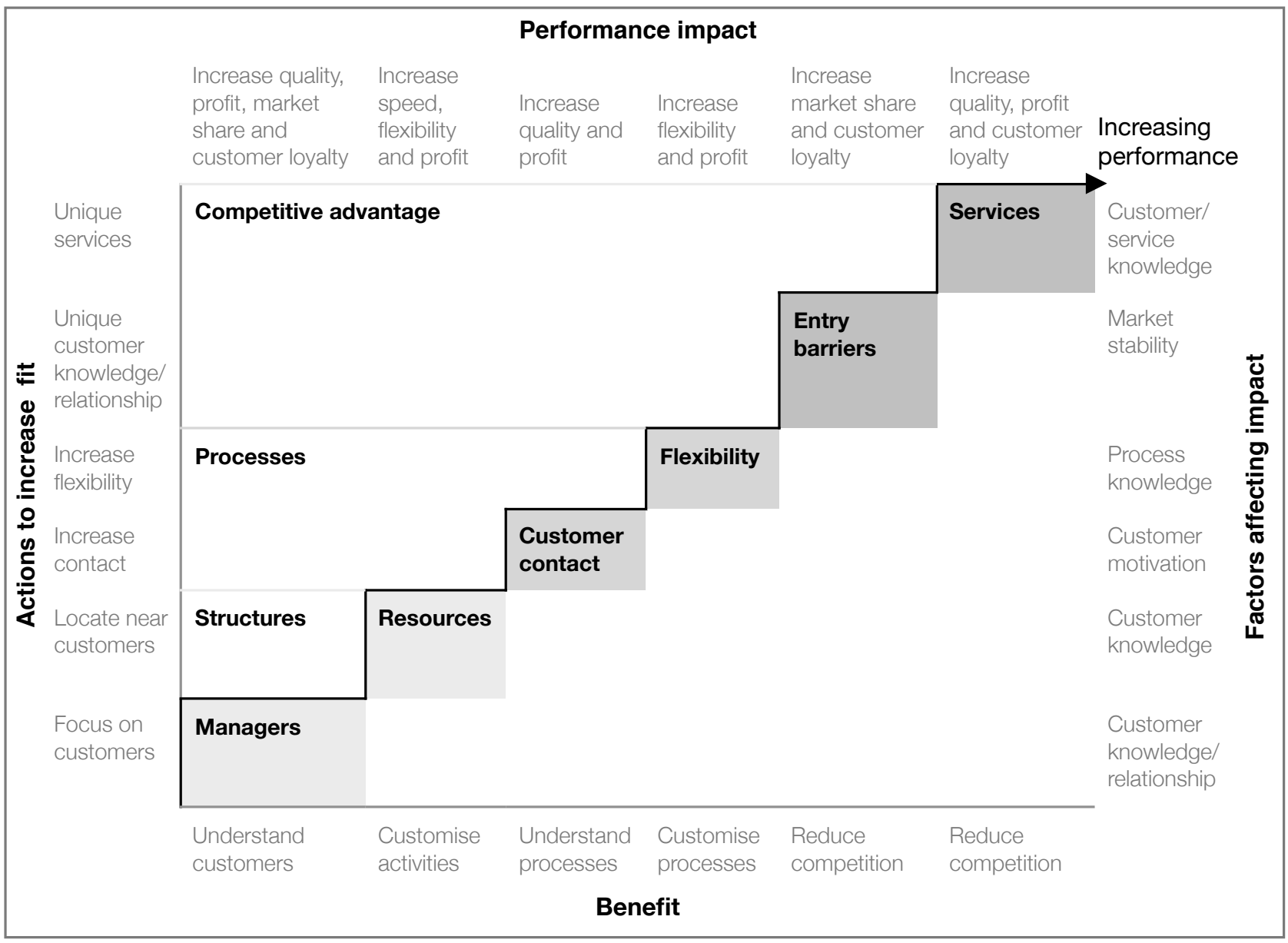




\section{Appendix 1}

Case study methodology based on Eisenhardt (1989)

Step Summary

1. Getting Research aimed to answer two questions:

started - $\quad$ What is the relationship between internal fit and business performance in service organisations?

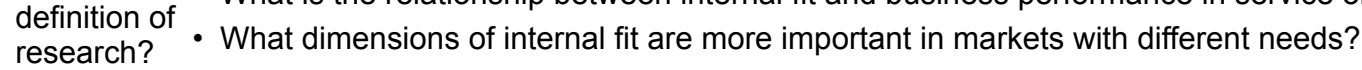

2. Selecting Eleven SBUs were identified by the research team (working with 7 partnering organisations) to provide a range of case cases studies with differing levels of business performance across 2 variables:

- Financial (operating profit relative to competitors)

- Competitiveness (domestic market share relative to competitors)

Serving markets with differing needs across 2 variables:

- How are orders won? (low cost or differentiation)

- Customer order volume (high or low volume)

3. Crafting Internal fit and business performance literature was reviewed to develop protocols (available from the authors) for the protocol semi-structured interviews, observations, case study write ups and cross-case analyses

4. Entering Each case study started with an initial field visit to review preliminary information, agree access and confidentiality and the field determine the executives to be interviewed, observations to be made and archival records, documents and reports to be reviewed

Subsequent interviews were conducted face-to-face at the companies' facilities. During these interviews, the research team identified further people to interview, observations to make and archival records, documents and reports to be reviewed

Each case study took 5 to 8 months to complete and involved 6 to 18 visits, 13 to 36 interviews, 31 to 140 observations and analysis of 21 to 56 documents and 55 to 109 archival records

5. Analysing Findings were written up for each study using the protocol outlining the organisation characteristics, level of business data performance, market needs and structures, systems and processes used to deliver its services

Within each case, the current level of internal fit was determined and changes in internal fit and business performance over the last seven years identified

A 24 to 33 page report was presented back to each participating organisation to help increase the validity of the findings

The overall case database was continually reviewed to check it had the necessary characteristics to answer the research questions. It was felt theoretical saturation had been reached once 11 cases had been investigated

6. Shaping A cross-case analysis was completed across the 11 cases studies to compare their internal fit and performance hypotheses journeys over the last seven years and identify statistically significant relationships between their current levels of internal fit and business performance

Data within the case studies was then revisited to help test and explain the significant internal fit and business performance relationships identified

7. Enfolding Findings were then compared with those from previous research into internal fit, business performance and other literature relevant aspects of operations management and organisation theory

8. Reaching Iterative analysis continued until theoretical saturation was reached and new evidence ceased to appear (Strauss and closure Corbin, 1990) 
Appendix 2

Data collected and analysed in each case study

\begin{tabular}{|c|c|c|c|c|c|c|c|c|c|c|c|c|}
\hline \multirow{2}{*}{\multicolumn{2}{|c|}{ Type of executive, direct observation, document or archival record }} & \multicolumn{11}{|c|}{ Number interviewed, observed or reviewed in each case study } \\
\hline & & 1 & 2 & 3 & 4 & 5 & 6 & 7 & 8 & 9 & 10 & 11 \\
\hline \multicolumn{13}{|l|}{ Executives interviewed } \\
\hline \multirow[t]{5}{*}{ Function } & Managing Director & 1 & 1 & 1 & 1 & 1 & 1 & 1 & 1 & 1 & 1 & 1 \\
\hline & Operations & 25 & 10 & 10 & 8 & 11 & 16 & 26 & 6 & 6 & 9 & 25 \\
\hline & Sales and Marketing & 2 & 3 & 3 & 7 & 10 & 3 & 7 & 4 & 5 & 11 & 2 \\
\hline & Other & 2 & 2 & 5 & 2 & 2 & 2 & 2 & 2 & 2 & - & 2 \\
\hline & Total & 30 & 16 & 19 & 17 & 24 & 24 & 36 & 13 & 14 & 21 & 30 \\
\hline \multirow{5}{*}{$\begin{array}{l}\text { \# levels beneath the } \\
\text { Managing Director }\end{array}$} & 0 & 1 & 1 & 1 & 1 & 1 & 1 & 1 & 1 & 1 & 1 & 1 \\
\hline & 1 & 5 & 4 & 5 & 4 & 4 & 4 & 5 & 5 & 5 & 3 & 5 \\
\hline & 2 & 8 & 5 & 7 & 5 & 5 & 8 & 11 & 7 & 8 & 8 & 8 \\
\hline & 3 & 16 & 6 & 6 & 7 & 14 & 11 & 18 & - & - & 9 & 16 \\
\hline & Total & 30 & 16 & 19 & 17 & 24 & 24 & 36 & 14 & 14 & 21 & 30 \\
\hline \multicolumn{13}{|l|}{ Direct observation of } \\
\hline Customer behaviour & $\begin{array}{l}\text { Listen to telephone calls and observe face-to-face } \\
\text { interactions }\end{array}$ & 8 & 33 & 37 & 42 & 46 & 34 & 10 & 12 & 23 & 37 & 31 \\
\hline Strategy & Strategy meetings & 2 & 4 & 6 & 2 & 8 & 8 & 7 & 3 & 2 & 8 & 6 \\
\hline Management & Management meetings & 5 & 8 & 8 & 6 & 7 & 8 & 4 & 5 & 4 & 8 & 4 \\
\hline Investment & Where investment have been made & 5 & 8 & 8 & 1 & 9 & 14 & 4 & 8 & 7 & 12 & 8 \\
\hline $\begin{array}{l}\text { Organisational } \\
\text { centralisation }\end{array}$ & Back-office and front-office layouts & 5 & 8 & 8 & 1 & 9 & 8 & 4 & 8 & 7 & 8 & 8 \\
\hline Service delivery & $\begin{array}{l}\text { Listen to telephone calls, observe front-office operations } \\
\text { and customer meetings }\end{array}$ & 8 & 33 & 37 & 42 & 46 & 34 & 10 & 12 & 23 & 37 & 31 \\
\hline Competitor analysis & $\begin{array}{l}\text { Observe service delivery and customer behaviour of } \\
\text { competitors }\end{array}$ & 4 & 12 & 13 & 13 & 15 & 6 & 3 & 3 & 5 & 6 & 5 \\
\hline Total & & 37 & 106 & 117 & 107 & 140 & 112 & 42 & 51 & 71 & 116 & 93 \\
\hline \multicolumn{13}{|c|}{ Documents reviewed } \\
\hline Business performance & $\begin{array}{l}\text { Industry reports and those commissioned by the } \\
\text { business itself }\end{array}$ & 5 & 16 & 15 & 5 & 12 & 5 & 12 & 7 & 5 & 5 & 7 \\
\hline Strategy & $\begin{array}{l}\text { Strategic and investment plans, budget reviews and } \\
\text { meeting minutes }\end{array}$ & 4 & 8 & 7 & 4 & 6 & 4 & 4 & 4 & 2 & 4 & 5 \\
\hline Management & Reports and meeting minutes & 4 & 11 & 7 & 4 & 15 & 4 & 2 & 6 & 5 & 4 & 5 \\
\hline Human resource & $\begin{array}{l}\text { Employee contracts, incentive schemes and personal } \\
\text { development plans }\end{array}$ & 8 & 8 & 9 & 3 & 13 & 5 & 3 & 7 & 4 & 5 & 4 \\
\hline Service delivery & $\begin{array}{l}\text { Working procedures, meeting minutes and industry } \\
\text { reports }\end{array}$ & 2 & 6 & 8 & 3 & 5 & 4 & 3 & 3 & 4 & 3 & 4 \\
\hline Competitor analysis & $\begin{array}{l}\text { Industry reports and those commissioned by the } \\
\text { business itself }\end{array}$ & 2 & 3 & 3 & 2 & 5 & 3 & 6 & 3 & 3 & 4 & 2 \\
\hline Total & & 25 & 52 & 49 & 21 & 56 & 25 & 30 & 30 & 23 & 25 & 27 \\
\hline \multicolumn{13}{|c|}{ Archival records reviewed } \\
\hline Business performance & $\begin{array}{l}\text { Financial accounts, management reports and other } \\
\text { reports }\end{array}$ & 5 & 8 & 12 & 5 & 10 & 6 & 8 & 7 & 5 & 6 & 8 \\
\hline Market research & $\begin{array}{l}\text { Industry reports and those commissioned by the } \\
\text { business itself }\end{array}$ & 2 & 6 & 10 & 4 & 8 & 4 & 12 & 7 & 6 & 4 & 8 \\
\hline Customer surveys & $\begin{array}{l}\text { Industry reports and those commissioned by the } \\
\text { business itself }\end{array}$ & - & 5 & 8 & - & 6 & 7 & - & 1 & 4 & 7 & 3 \\
\hline Customer behaviour & Order and communication history & 2 & 3 & 7 & 2 & 6 & 5 & 12 & 2 & 4 & 5 & 3 \\
\hline Strategy & $\begin{array}{l}\text { Strategy implementation reports, documents and } \\
\text { communications }\end{array}$ & 4 & 2 & 5 & 4 & 4 & 2 & 4 & 4 & 2 & 2 & 5 \\
\hline $\begin{array}{l}\text { Operational } \\
\text { performance }\end{array}$ & $\begin{array}{l}\text { Historical performance and comparison against plans } \\
\text { and targets }\end{array}$ & 4 & 4 & 7 & 4 & 6 & 7 & 2 & 9 & 8 & 7 & 7 \\
\hline Management Structure & $\begin{array}{l}\text { Organisational charts and functions, roles and } \\
\text { responsibilities }\end{array}$ & 8 & 14 & 19 & 5 & 12 & 16 & 8 & 12 & 14 & 11 & 13 \\
\hline $\begin{array}{r}\text { Organisational } \\
\text { centralisation }\end{array}$ & Office and geographical layouts & 10 & 16 & 8 & 5 & 9 & 8 & 4 & 14 & 10 & 8 & 15 \\
\hline Investment & $\begin{array}{l}\text { Financial budgets, actual investments and training } \\
\text { records }\end{array}$ & 2 & 4 & 6 & 2 & 4 & 2 & 4 & 6 & 3 & 2 & 4 \\
\hline Management & Management reports & 8 & 9 & 8 & 14 & 11 & 6 & 16 & 6 & 9 & 6 & 12 \\
\hline Human resource & Salaries, bonuses and training records & 2 & 3 & 4 & 2 & 4 & 4 & 2 & 2 & 4 & 3 & 4 \\
\hline Service delivery & $\begin{array}{l}\text { Working procedures, office layouts and equipment } \\
\text { investment }\end{array}$ & 5 & 4 & 9 & 5 & 8 & 3 & 3 & 10 & 5 & 3 & 6 \\
\hline Competitor analysis & $\begin{array}{l}\text { Industry reports and those commissioned by the } \\
\text { business itself }\end{array}$ & 3 & 3 & 6 & 4 & 5 & 6 & 9 & 5 & 4 & 8 & 4 \\
\hline Total & & 55 & 81 & 109 & 56 & 93 & 76 & 84 & 85 & 78 & 72 & 92 \\
\hline
\end{tabular}


Appendix 3

Business performance measures

\begin{tabular}{|c|c|c|}
\hline Dimension and variable & Definition & Scale \\
\hline \multicolumn{3}{|l|}{ Operational performance } \\
\hline Cost & $\begin{array}{l}\text { Operating costs as a percentage of sales revenue relative to } \\
\text { competitors }\end{array}$ & $\begin{array}{l}0(80 \% \text { of competitor average })- \\
5(120 \% \text { of competitor average })\end{array}$ \\
\hline Flexibility & Range of services delivered to customers relative to competitors & $\begin{array}{l}0(80 \% \text { of competitor average })- \\
5(120 \% \text { of competitor average })\end{array}$ \\
\hline Speed & Length of time to fulfil a customer order relative to competitors & $\begin{array}{l}0 \text { ( } 80 \% \text { of competitor average })- \\
5(120 \% \text { of competitor average })\end{array}$ \\
\hline Quality & $\begin{array}{l}\text { Customer satisfaction with the service delivered relative to } \\
\text { competitors }\end{array}$ & $\begin{array}{l}0 \text { ( } 80 \% \text { of competitor average })- \\
5(120 \% \text { of competitor average })\end{array}$ \\
\hline \multicolumn{3}{|l|}{ Financial performance } \\
\hline Profit & $\begin{array}{l}\text { Operating profit before interest and taxes as a percentage of sales } \\
\text { revenue relative to competitors }\end{array}$ & $\begin{array}{l}0 \text { ( } 80 \% \text { of competitor average })- \\
5(120 \% \text { of competitor average })\end{array}$ \\
\hline \multicolumn{3}{|l|}{ Competitiveness } \\
\hline Market share & $\begin{array}{l}\text { Percentage of the total domestic market revenue relative to } \\
\text { competitors }\end{array}$ & $\begin{array}{l}0 \text { ( } 80 \% \text { of competitor average })- \\
5(120 \% \text { of competitor average })\end{array}$ \\
\hline Customer loyalty & $\begin{array}{l}\text { Length of time that a customer continues to place orders with the } \\
\text { organisation relative to competitors }\end{array}$ & $\begin{array}{l}0(80 \% \text { of competitor average })- \\
5(120 \% \text { of competitor average })\end{array}$ \\
\hline
\end{tabular}

\section{Appendix 4}

Internal fit measures

\begin{tabular}{lll}
\hline Dimension and variable & Definition & Scale \\
\hline Market needs &
\end{tabular}

Key market order-winner Importance of 'have better designed services/products' in winning orders

Importance of 'have lower selling price' in winning orders

0 (very important) 5 (not important)

0 (not important) -

5 (very important)

Customer order volume

Volume of orders placed by a customer in a year

0 (less than 5$)-$

5 (more than 1,000$)$

\section{Structures}

Organisational centralisation Percentage of activities centralised across operations units

$0(0 \%)-5(100 \%)$

Management structure

Percentage of activities structured around customers rather than processes

$0(100 \%)-5(0 \%)$

Systems

Performance measures

Percentage of measures used to monitor and develop customer support

$0(100 \%)-5(0 \%)$

Percentage of measures used to monitor and reduce costs

$0(0 \%)-5(100 \%)$

Employee rewards and

Percentage of employee incentives, rewards and developments linked to

$0(100 \%)-5(0 \%)$

developments

improving customer support

Percentage of employee incentives, rewards and developments linked to

$0(0 \%)-5(100 \%)$ reducing costs

Quality management

Percentage of service quality checks completed by technology/equipment rather than people

Capacity management

Percentage of capacity management decisions completed by technology/ equipment rather than people

\begin{tabular}{|c|c|c|}
\hline \multicolumn{3}{|l|}{ Processes } \\
\hline Flexibility & $\begin{array}{l}\text { Level of investment required to modify system to deliver new service/product } \\
\text { designs }\end{array}$ & $\begin{array}{l}0 \text { (very significant) - } \\
5 \text { (not significant) }\end{array}$ \\
\hline Automation & Percentage of steps processed by a technology/equipment rather than people & $0(0 \%)-5(100 \%)$ \\
\hline Level of customer contact & Percentage of tasks completed in the presence of the customer & $0(100 \%)-5(0 \%)$ \\
\hline Type of customer contact & Percentage of tasks completed face-to-face with the customer & $0(100 \%)-5(0 \%)$ \\
\hline \multicolumn{3}{|l|}{ Competitive advantage } \\
\hline \multirow[t]{3}{*}{ Barriers to entry } & 'Low cost capability' compared with competitors & $\begin{array}{l}0 \text { (not significant) - } \\
5 \text { (very significant) }\end{array}$ \\
\hline & 'Technical capability' compared with competitors & $\begin{array}{c}0 \text { (very significant) - } \\
5 \text { (not significant) }\end{array}$ \\
\hline & 'Customer knowledge' and 'customer relationships' compared with competitors & $\begin{array}{l}0 \text { (very significant) - } \\
5 \text { (not significant) }\end{array}$ \\
\hline Service differentiation & Percentage of service/product designs that are also delivered by competitors & $0(0 \%)-5(100 \%)$ \\
\hline
\end{tabular}




\section{Appendix 5}

Key data used to measure performance and market needs

\begin{tabular}{l}
$\begin{array}{l}\text { Type of direct observation, document or } \\
\text { archival record }\end{array}$ \\
\cline { 2 - 7 }
\end{tabular}


Appendix 6

Key data used to measure structures, systems, processes and competitive advantage

Type of executive, direct observation, document or archival record

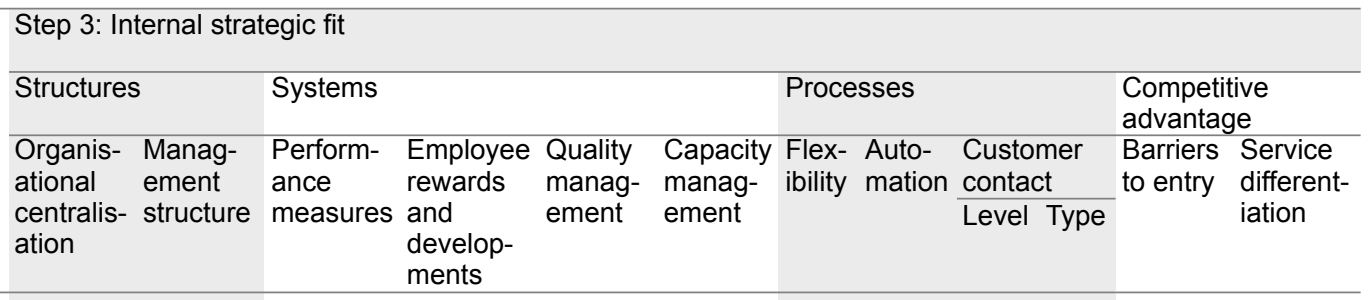

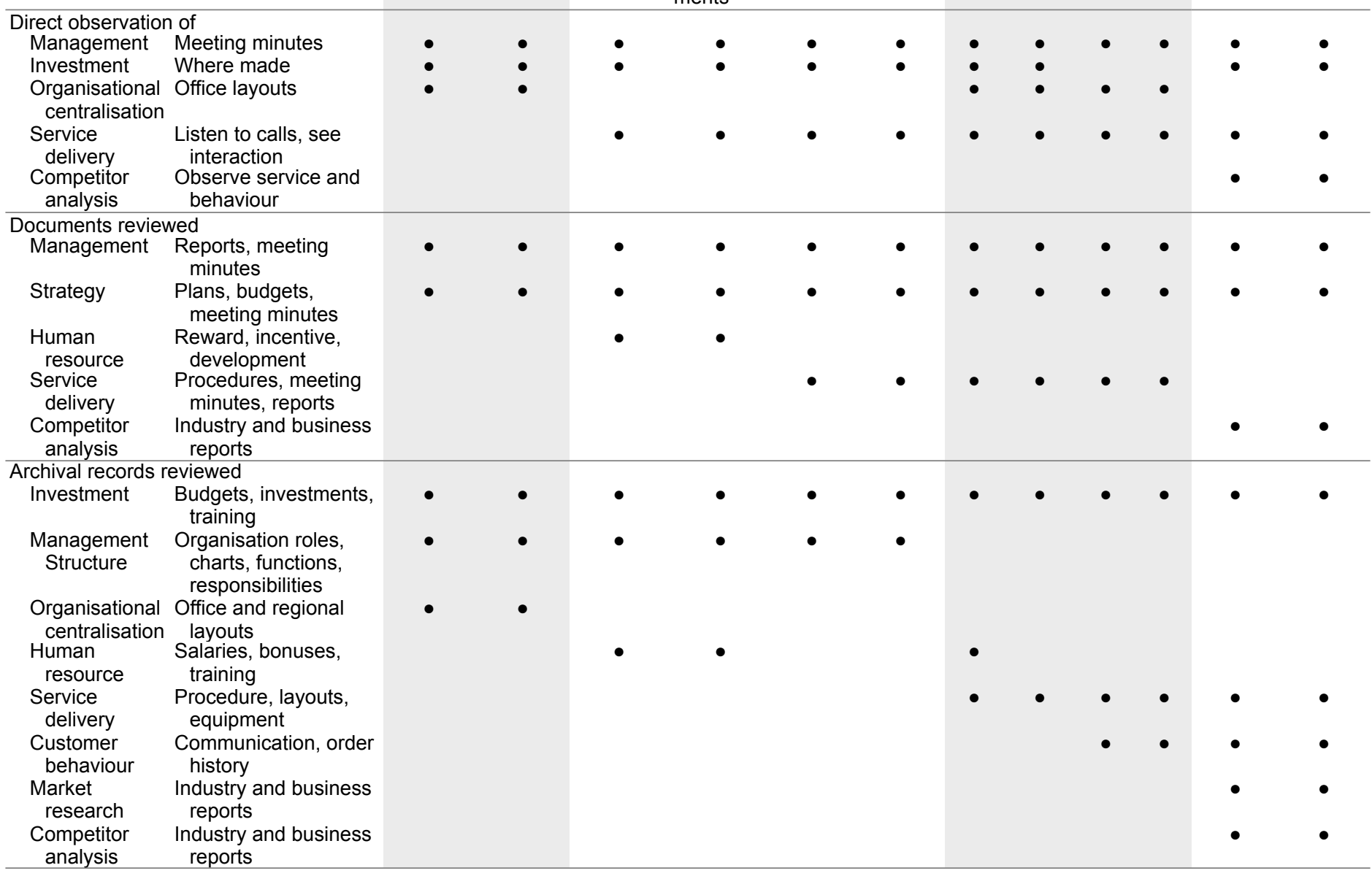

